\title{
Üreticileri Tersine Lojistik Faaliyetlerine Yönelten Motivasyonlar Hiyerarşisi
}

\section{The Hierarchy of Motivations Turning Manufacturers'Attention to Reverse Logistics}

Metehan Feridun SORKUN ${ }^{1}$

\section{ÖZET}

$\mathrm{Bu}$ çalışma, üretici firmaları tersine lojistik uygulamalarına yönelten motivasyonları hiyerarşik bir yapıda göstermeyi amaçlamaktadır. Tersine lojistik faaliyetlerinin etkin bir şekilde uygulanması operasyon maliyetlerini azaltmakta, müşteri memnuniyetini arttırmakta ve çevreye duyarlı bir üretim süreci oluşturarak firmaların marka değerlerini güçlendirmektedir. Tersine lojistik süreçlerinin bir çok farklı hedefe hizmet etmesi, bu çalışmayı Türkiye'deki üretici firmaların hangi temel motivasyon ile tersine lojistik faaliyetlerine yöneldiklerinin sorusunun cevabını aramaya yöneltmiştir. Bu amaçla elektrik-elektronik sektöründe de faaliyet gösteren, Türkiye'nin en güçlü markalarından olan Vestel firmasının tersine lojistik süreçleri incelenmiştir. Tersine lojistik ile ulaşılmaya çalışılan hedeflerin birbirleriyle olan ilişkileri hem mevcut sektör şartları düşünülerek hem de kuramsal çerçevede nominal grup tekniğiyle tartışılmıştır. Elde edilen veriler ışığında "yorumlayıcı yapısal modelleme" yöntemi kullanılarak firmaları tersine lojistik uygulamalarına yönelten motivasyonların hiyerarşik yapısı ortaya çıkarılmıştır. Hiyerarşide tespit edilen itici motivasyonlar, Türkiye'deki politika yapıcılarına tersine lojistik uygulamalarının teşviki için politika üretme fırsatı verecektir. Benzer şekilde, üretici firmalar da bu temel itici motivasyonları göz önünde bulundurarak strateji oluşturabilecek ve böylece birçok farklı hedefi beraber gerçekleştirebilecektir.

Anahtar Kelimeler: tersine lojistik, yorumlayıcı yapısal modelleme, geri dönüşüm, atık yönetimi, ürün iade yönetimi, kapalı döngü tedarik zinciri.

0000-0002-9699-4243

\begin{abstract}
The aim of this study is to outline the motivating factors hierarchically, which turn the manufacturing firms' attention to reverse logistics. Effective reverse logistics management provides many advantages such as reducing operational costs, increasing customer satisfaction, boosting brand value, and meeting the requirements of environmental regulations. Since reverse logistics helps firms to accomplish wide range of goals, this research searches for the fundamental motivation of Turkish manufacturers to give emphasis on reverse logistics. To this end, this study examines the reverse logistics processes of the Turkish giant manufacturing company, Vestel, for its electricelectronic product groups. The nominal group technique is applied with the participation of Vestel managers, which provides the data on how the goals aimed to accomplish via reverse logistics interrelate. Then, interpretative structure modelling is used to establish the hierarchy of reverse logistics motivation factors. This hierarchy shows the fundamental motivations through which it is possible to accomplish many goals together. Hence, the results of this study give guidance to both policy makers and managers in formulating their product return policies and strategies.
\end{abstract}

Keywords: reverse logistics, interpretative structure modelling, recycling, waste management, product recovery management, closed-loop supply chain management.

\section{Gíriş}

Satın aldığı üründen memnun kalmayan veya aldığı ürünle alakalı sorun yaşayan müşterilerden ürünlerin geri dönmesi, satılamayan malların pera- kendeciler tarafından üreticiye geri gönderilmesi, ürün yaşam döngüsü sona ermiş olan ürünlerin toplanarak geri dönüştürülmesi gibi farklı sebeplerden ötürü firmaların tedarik zincirinde geriye doğru ürün 
akışı bulunmaktadır (Govindan vd., 2012). Tersine lojistik yönetimi, tüketim noktasına yakın tedarik zinciri üyelerinden üretim noktasına yakın olan üyelerine doğru var olan ürün geri akışını etkin ve çevreye duyarlı bir şekilde yöneterek maksimum değer elde etmeyi amaçlamaktadır (Rogers ve Tibben-Lembke, 1999).

Teknolojinin hızla gelişmesi ile ürün yaşam döngülerinin kısalması ve bununla birlikte küreselleşme ile yeni pazarların oluşmaya devam etmesi üretim miktarlarını her geçen gün arttırmaktadır. Bu durumun neticesi olarak tersine lojistik süreçlerinin etkin bir şekilde yönetilmesi üretici firmalar için birçok nedenden ötürü önem teşkil etmektedir. Öncelikle satın aldığı ürünlerle alakalı sorun yaşayan müşterilerin sorunlarının giderilmesi müşteri memnuniyetine ve sadakatine pozitif yönde etki etmektedir (Silva vd., 2013). Geri dönen ürünlerin geri kazanılıp tekrar üretime sokulması ile üretim maliyetleri azaltılabilirken, ikinci el piyasalarda bu ürünler tekrar satılarak ek bir gelir de elde edilebilmektedir (Ye vd., 2013). Tersine lojistik ile üretimde azalan kaynak kullanımı, firmalara çevreci bir imaj kazandırmaktadır (Srivastava, 2008). Ayrıca günümüz çevre yönetmeliklerinin, üretilen ürünlerin geri toplanmasını zorunlu kılması da tersine lojistik süreçlerinin iyi yönetilmesinin önemini arttırmaktadır (Demirel vd., 2016).

Yapılan çalışmalar, tersine lojistik uygulamalarının operasyon maliyetlerini düşürme, yasal yükümlülükleri yerine getirme, güçlü marka oluşturma ve ekonomik değer elde etme gibi pek çok motivasyonu barındırdığını göstermiştir (Sorkun ve Onay, 2018). Fakat bu motivasyonlarla ilişkili hedeflerin birbiriyle bağlantısını ortaya koyan bir çalışma bulunmamaktadır. Bir diğer deyişle, tersine lojistik ile amaçlanan bir hedefe ulaşılmasının, diğer hedeflerin başarılmasına nasıl katkısı olabileceği daha önce araştııılmamıştır. Bu amaçla, Türkiye'nin en büyük üreticilerinden olan Vestel'in elektrik ve elektronik ürün gruplarının tersine lojistik süreçleri incelenmiştir. Elde edilen veriler, "yorumlayıcı yapısal modellemesi" yöntemi kullanılarak analiz edilmiştir. Yapılan bu analiz, Vestel'i tersine lojistik aktivitelerine yönelten hedeflerin birbiriyle olan ilişkilerini ortaya koymuştur. Böylece, günümüzde üreticileri tersine lojistik uygulamalarına yönelten temel motivasyonlar tespit edilmiştir.

Bu çalışmanın ana çıktısı olan tersine lojistik motivasyon faktörleri hiyerarşisi, üreticileri tersine lojistiğe yönelten temel ana motivasyonları ve bu motivasyonlara bağlı hedefler arasındaki ilişkileri göstererek önemli bir teorik katkı sunmayı amaçlamaktadır. $\mathrm{Bu}$ çalışmanın sonuçlarından pek çok yönetimsel çıkarımlar yapmak da mümkün olabilecektir. Sektör koşulları ve kısıtları göz önünde bulundurularak oluşturulan güncel tersine lojistik motivasyon faktörleri hiyerarşisi, politika yapıcılarına hangi hedefe yönelik teşvik sağlanabileceği veya hangi konularda ek tedbir alınabileceği hakkında ipucu verebilecektir. Yöneticiler de pek çok hedefin gerçekleşmesine yardım edecek motivasyonun ne olduğunu bilebilecek ve böylece bu motivasyonun ön planda tutulduğu stratejilerle firmalarını pek çok hedefe aynı anda ulaştırma şansını yakalayabilecektir. Ayrıca bu çaış̧ma, var olan sektör ve işletme kısıtları olmasaydı tersine lojistik motivasyon faktörleri hiyerarşisinin nasıl değişeceğini uzman görüşlerini alarak kuramsal çerçevede göstermeyi de hedeflemiştir. İki hiyerarşik yapı arasındaki farkın iyi yorumlanması yine politika yapıcılarına gerekli düzenlemeleri yapma fırsatı vererek firmaların gönüllü bir şekilde tersine lojistik süreçlerine yatırım yapmalarını sağlayabilecektir.

\section{LITERATÜR ÖZETi}

\subsection{Tersine Lojistik Yönetimine Özgü Zorluklar}

Tersine lojistik yönetimi, tüketim noktasından üretim noktasına olan ürün geri akışının yönetimini ifade etmektedir. Ürünlerin geri akışının yönetimi, ileri lojistik yönetimine (ürünlerin üretim noktasından tüketim noktası yönüne akışının yönetimine) kıyasla kendine özgü pek çok zorluğu beraberinde getirmektedir. Öncelikle, ürün geri akışının içerdiği belirsizliğin nispeten daha çok olması, planlama yapmayı zorlaştırmaktadır. İleri lojistikte talep tahmini yapılarak önceden aksiyon alınabilirken, tersine lojistikte geri dönüşümü yapılacak ürünün durumunun, miktarının ve ne zaman geri dönüşünün yapılacağının bilinmemesi bu sürecin yönetilmesini daha zorlaştırmaktadır (Kara vd., 2007). Geri dönüşlerin topluca olmaması, yapılacak işlemlerde ve nakliyat süreçlerinde ölçek ekonomisinden yararlanılmasını zorlaştırmaktadır (Tibben-Lembke ve Rogers, 2002). Ayrıca geri dönüşü yapılan üründen yüksek değer sağlayacak işlemin ne olduğunun ortaya çıkarılması için uzman kararının beklenmesi gerekmektedir. Fakat bu bekleme süresi uzadıkça, tersine lojistik aktiviteleri ile üründen geri kazanılacak değerin azalması bir diğer yönetimsel zorluk olarak göze çarpmaktadır (Blackburn vd., 2004). 


\subsection{Geri Dönen Ürünlerin Değerlendirilmesinde Kullanılan Alternatif Yöntemler}

Geri dönen ürünler toplandıktan sonra herhangi bir ekonomik değer elde edilip edilemeyeceği kontrol edilmek üzere incelenmektedir. Hiçbir ekonomik değer elde edilme imkânı olmayan geri dönüşleri, firmalar çevreye duyarlı bir şekilde bertaraf etme sorumluluğundadır. Eğer bir ekonomik değer oluşturulma imkânı varsa bu iki farklı şekilde gerçekleştirilebilmektedir. Illk alternatif, geri dönüşü yapılan ürünlerin herhangi bir işlem görmeden ikinci piyasalarda yeniden satılması ya da hâla iş gören parçalarının başka ürünlerde direk kullanılarak değerlendirilmesidir. İkinci alternatif ise tamir etme, yeniden üretim ve geri dönüştürme gibi çeşitli tersine lojistik aktiviteleri uygulanarak geri dönen ürünlerin tekrar ileri lojistik akımına sokularak geri kazanılmasıdır. "Ürün tamiri", ürünün yerine getiremediği fonksiyonları geri kazandırmayı; "yeniden üretim" ürünün tekrar orijinal ürün kalitesinde üretilmesini; "geri dönüştürme" ise yeni ürünlerin üretiminde kullanılabilecek temel ürün malzemelerinin (plastik, cam vb.) elde edilmesini ifade etmektedir (Sorkun ve Onay, 2016). Şekil 1, geri dönen ürünlerin nasıl farklı yollarla değerlendirilebileceğini göstermektedir.

\subsection{Tersine Lojistik Motivasyon Faktörleri}

Agrawal vd. (2015) tarafından yapılan literatür araştırması, firmaların tersine lojistik aktivitelerine yönelmesi için bir çok motivasyon faktörünün bulunduğunu göstermiştir. Buna bağlı olarak geçmiş çalışmalar tarafından sıkça telaffuz edilen ve bu çaIışmanın analizinde de yer alan motivasyon faktörleri aşağıda gerekçeleriyle açıklanmaktadır.

Tersine lojistik faaliyetlerinin etkinliğinin müşteri memnuniyeti üzerinde direk etkisi olduğu belirtilmektedir (Daugherty vd., 2002). Müşteriler, ürünleri ile alakalı sorunların hızlı bir şekilde giderilmesi durumunda daha çok memnuniyet duymaktadır. Etkin tersine lojistik yönetimi ile firmalar, ürün geri kabul politikalarında esnek olabilmekte, ürünleri hızlı bir şekilde geri toplayıp inceledikten sonra tamir veya değişim gibi gerekli işlemleri yaparak müşterilerinin problemlerini çözebilmektedir. Bunun neticesi olarak da iyi ve etkin bir tersine lojistik yönetiminin müşterilerin gelecek yeniden satın alma davranışlarını beslediği dile getirilmektedir (Jayaraman ve Luo, 2007).

Tersine lojistik süreçlerinin düzgün bir şekilde yürütülmesinin kurum imajına pozitif tesiri olduğu ifade edilmektedir (Carter ve Elram, 1998). "Sürdürülebilirlik", "yeşil tedarik zinciri", ve "kurumsal sosyal sorumluluk" gibi günümüzde popülerleşen terimler, firmaların topluma ve doğaya karşı sorumlu olduklarını hatırlatmaktadır. Etkin tersine lojistik yönetimi ile ürünlerin geri dönüştürülerek az kaynak kullanımının sağlanması ve ürünlerin çevreye duyarlı bir şekilde bertaraf edilmesi firmaların kurum imajlarına pozitif yönde etki etmektedir (Kumar ve Putnam, 2008). Bunun sonucu olarak da söz konusu firma, tüketicilerin tercih ettiği, nitelikli iş gücünün çalışmak istediği ve yatırımcıların yatırım yapmaya hazır olduğu bir kurum haline gelmektedir.

Şekil 1: Geri Dönen Ürünlerin Değerlendirilmesinde Kullanılan Alternatif Yöntemler

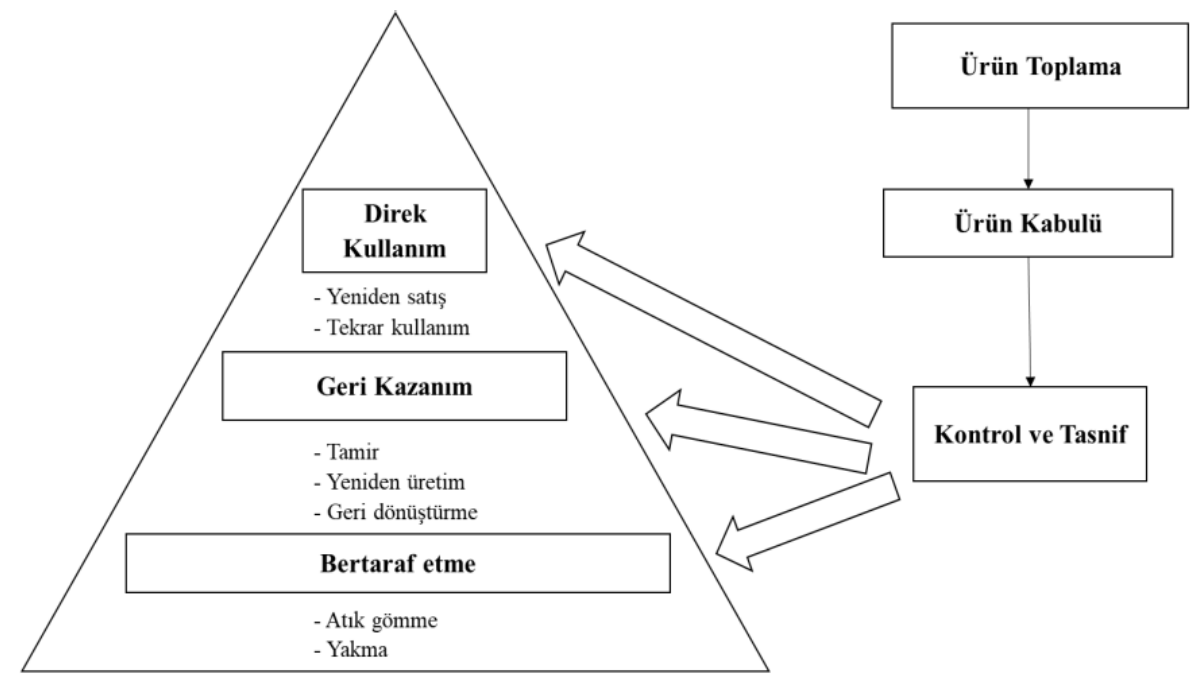


Tersine lojistik aktivitelerinin sağladığı finansal faydalar da göze çarpmaktadır. Geri dönen ürünlerin ikinci el piyasalarda tekrar satışı firmalar için önemli bir gelir kalemi olabilmektedir. Kumar ve Putnam (2008), Xerox firmasının fotokopi makinelerini 10 defaya kadar farklı kullanııılara kiralayabildiğini bu duruma örnek olarak göstermiştir. Her kira süresi tamamlandığında bu makinelerin çeşitli işlemlerden geçirilerek başka kullanıcılara kiralanmaya hazır hale getirildiği ve böylece Xerox'un önemli bir gelir elde ettiği paylaşılmıştır. Bir diğer yandan firmalar, kullanılmış veya defolu ürünlerini indirim mağazalarında yeniden satarak farklı fiyat uygulaması yoluyla cirolarını arttırabilmektedir (Blackburn vd., 2004). Ayrıca, elektrik-elektronik sektörünün oluşturmuş olduğu atıkların altın, gümüş ve platin gibi değerli metalleri barındırdığı bilinmektedir (Ravi, 2012). Bu değerli metalleri tersine lojistik işlemlerinden geçirerek ekonomik bir şekilde çıkartabilen firmalar önemli bir finansal kazanç elde edebilmektedir.

Kanun koyucular tarafından insan ve çevre sağlığını gözetmek amacıyla konulan kurallar firmaların tersine lojistik faaliyetlerine daha çok önem vermesini sağlamıştır. Türkiye'de üretim yapan firmaların faaliyetleri, çeşitli yönetmeliklerle gün geçtikçe daha sıkı bir şekilde kontrol edilmektedir. Örneğin 2010'da Çevre ve Orman Bakanlığı'nın Resmi Gazete'de yayımladığı yönerge, araç üreticilerine ürün yaşam döngüsü tamamlanmış araçları bir bedel talep etmeksizin geri toplayıp çevreye duyarlı şekilde bertaraf etme yükümlülüğü getirmiştir (Demirel vd., 2016). Aynı şekilde 22 Mayıs 2012 tarihinde Çevre ve Orman Bakanlığı tarafından yayımlanan yönetmelik, atık elektrik elektronik eşyaların (AEEE) geri dönüşümünü kontrol altına alma hedefi kapsamında üreticilerin sorumluluklarını belirlemiştir. Buna göre, elektrik ve elektronik sektöründe üretim yapan firmalar $A B$ uyum mevzuatı çerçevesinde sattıkları ürünlerin ağırlıklarının önemli bir yüzdesini geri toplamak, dönüştürmek, kazanmak veya bertaraf etme sorumluluğundadır (AEEE Kontrolü Yönetmeliği, 2012). Bu hedefleri gerçekleştiremeyen üreticilere cezai işlem uygulanması planlanmaktadır. Cezaların caydırıcı etkisinin yanı sıra, devlet teşvikleri de firmaların tersine lojistik aktivitelerine yatırım yapmasında önemli bir rol oynayabilmektedir (Kulshreshtha ve Sarangi, 2001). Aksen vd. (2009), firmaların geri topladığı ürünler için devletin ücret ödemesi ve çeşitli politikalarla firmaları desteklemesi durumunda daha çok ürünün toplanabileceğini ve firmaların daha çok kâr elde edebileceğini göstermiştir.
Tersine lojistik faaliyetleri ile oluşan "kapalı tedarik zinciri döngüsü"stok, nakliye ve satın alma gibi önemli lojistik maliyetlerini azaltmaktadır (Daugherty vd., 2002). Kapalı tedarik zinciri döngüsünde ürünlerin akışı son tüketicide sonlanmamakta, geri kazanılarak ileri lojistik akımını beslemektedir (Jayaraman vd., 2008). Bu çerçevede geri kazanılan ürün parçaları, yedek parça olarak kullanılabilmektedir. Tamiri yapılan ürünler tekrar mağazalara gönderilerek satılabilmekte ya da garanti değişimleri için tutulabilmektedir. Geri dönüşüm yoluyla hammadde elde edilmesi ise tedarikçilere olan bağımlılığı azaltmaktadır. Bunun sonucu olarak, malzeme/parça temin sürelerinin uzunluğunun ve değişkenliğinin azalması firmaların tutması gereken emniyet stok seviyesini azaltmaktadır (Biehl vd., 2007). Aynı şekilde satılan ürünlerden daha çok kullanılabilir parça kazanılması ve ürün malzemelerinin geri dönüştürülmesi, tedarikçilerden satın alınması gereken parça/malzeme miktarlarını azaltarak satın alma maliyetlerini düşürmektedir (Fleischmann vd., 2003). İhtiyaç olunan parçaların ve malzemelerin iç kaynaklardan daha fazla temin edilebilmesi ayrıca uzun mesafe taşımaları azaltarak nakliye masraflarını düşürmektedir (Huscroft vd., 2013).

Tersine lojistik süreçlerini iyi yöneten firmalar mevcut kalite problemlerini çözerek ürünlerinin kalitesini arttırabilmektedir (Tibben-Lembke, 2012). Geri dönen ürünlerin incelenmesiyle sık yaşanan kalite problemleri tespit edilebilmekte ve müşterilerin ürün deneyimlerini negatif yönde etkileyen ürün fonksiyonları hakkında bilgi elde edilebilmektedir. Geri ürün akışının beraberinde getirdiği bu geri bildirimlerin kullanılması firmaların ürün kalite programlarını pozitif şekilde etkilemektedir (Škapa ve Klapalová, 2012). Bu noktaya dikkat çeken Bernon vd. (2011), ürün geri toplama ve inceleme süreçleri için dış kaynak kullanımının riskli olabileceği uyarısında bulunmaktadır. Yazarlar, ürün geri dönüş nedenlerini dış kaynak kullanımından dolayı tam olarak kavrayamayan firmaların zamanla piyasa dinamiklerinden uzaklaşabileceği tehlikesine vurgu yapmaktadır.

Doğal kaynakların bilinçsizce tüketilmesine devam edilmesi durumunda, üretim girdilerinin yakın gelecekte ekonomik bir şekilde temin edilemeyeceği firmalar tarafından fark edilmiştir. Bu sebeple, yalnız yasal zorunlulukları ve müşteri algısını düşünerek değil aynı zamanda sürdürülebilir bir üretim için de firmalar, tedarik zinciri faaliyetlerinin çevreye yaptığı olumsuz etkileri azaltmayı amaçlamaktadır. Bu nok- 
tada, tersine lojistik aktivitelerinin etkin şekilde yönetilmesi, üretim süreçlerinin neden olduğu karbon ayak izini azaltmaktadır. Ürünlerin tamir edilip tekrar kullanılması, işlevini sürdüren ürün parçalarının tespit edilerek başka ürünlerde değerlendirilmesi, ürünlerin yeniden üretimi, bazı ürünlerin geri dönüştürülerek hammadde elde edilmesi süreçlerinin hepsi daha az kaynak kullanımını sağlamaktadır (Fleischmann vd., 2003). Ürün paketlerinin geri dönüştürülerek tekrar kullanılabilmesi karbon ayak izini azaltan diğer tersine lojistik aktivitesi olarak göze çarpmaktadır (Siva vd., 2013). Aynı şekilde, bertaraf edilecek atıkların veya geri dönüştürülecek ürün ve parçaların "sıkıştırma" yöntemi ile nakliye araçlarında daha az yer kaplamaları sağlanabilmektedir. Bunun sonucu olarak bir seferde daha çok ürün taşınabilmesi toplam yapılması gereken sefer sayısını düşürerek çevreye salınan karbon miktarını azaltmaktadır (Bai ve Sarkis, 2013).

Yukarıda gerekçeleriyle açıklanan tüm tersine lojistik motivasyon faktörleri başılılar halinde Tablo-1'de listelenmişstir:

\section{ARAŞTIRMANIN AMACI}

Bu çalışmanın iki temel amacı bulunmaktadır. Günümüzde üretici firmaları tersine lojistik aktivitelerine yönelten motivasyonların hiyerarşik yapısını ortaya koymak bu çalışmanın birinci amacını oluşturmaktadır. Bu amaç kapsamında ortaya çıkarılacak tersine lojistik motivasyon faktörlerinin hiyerarşisi, bu motivasyonlara bağlı her bir hedefin gerçekleştirilmesinin diğer hangi hedeflerin gerçekleştirilmesine katkı yapacağını gösterecektir. Bu hiyerarşi, yöneticilerin stratejik kararları için önemli bir girdi olabilecektir; çünkü hiyerarşinin alt kademelerinde yer alan itici motivasyonlara bağlı hedeflere odaklanan stratejiler diğer birçok hedefin de gerçekleşmesine yardımcı olabilecektir.

Bu araştırmanın ikinci amacl, tersine lojistik faktörleri hiyerarşisinin araştırma yapılan bağlama ve incelenen firmaya özgü kısıtlara bağlı olarak değişip değişmediğini kontrol etmektir. Çoğu sektör ve operasyonel kısıtlarının kaldırıması politika yapıcıların yapacağı yönetmelik değişiklikleriyle mümkün olabilmektedir. Dolayısıyla kısıtların var olduğu güncel hiyerarşi ile kısıtların olmadığı düşünülerek kuramsal çerçevede oluşturulan hiyerarşik yapı arasındaki farkların tespiti politika yapıcılarının kararları için önemli bir girdi olabilecektir. İki hiyerarşik yapının karşılaştırılması sonucu var olan farklılıkların toplam ekonomik refah seviyesini azaltan nitelikte olduğu tespit edildiği takdirde gerekli kısıtlar kaldırılarak veya ek kısıtlar koyularak daha fazla ekonomik refaha ulaşmak mümkün olabilecektir. Politika yapıcılar, alacakları kararlar ile hiyerarşide yer alan temel itici motivasyon faktörünü değiştirebilecektir. Böylelikle, firmaların tersine lojistik aktivitelerine zorunlulukla değil, gönüllü bir şekilde yönelmeleri sağlanabilecektir.

Tablo 1: Üreticileri Tersine Lojistik Faaliyetlerine Yönelten Motivasyonlar

\begin{tabular}{|c|c|c|}
\hline Motivasyon gösterimi & Tersine Lojistik Motivasyon Faktörleri & Kaynak \\
\hline$M_{1}$ & Tekrar satın alma davranışını besleme & $\begin{array}{l}\text { Daugherty vd. (2002) } \\
\text { Jayaraman ve Luo (2007) }\end{array}$ \\
\hline$M_{2}$ & Kurum imajını pozitif etkileme & $\begin{array}{l}\text { Carter ve Elram (1998) } \\
\text { Kumar ve Putnam (2008) }\end{array}$ \\
\hline$M_{3}$ & Finansal firsatlardan yararlanma & $\begin{array}{l}\text { Blackburn vd. (2004) } \\
\text { Kumar ve Putnam (2008) } \\
\text { Ravi (2012) }\end{array}$ \\
\hline$M_{4}$ & Kanuni yükümlülükleri yerine getirme & Demirel vd. (2016) \\
\hline$M_{5}$ & Devlet teşvik ve desteklerinden yararlanma & $\begin{array}{l}\text { Kulshreshtha ve Sarangi (2001) } \\
\text { Aksen vd. (2009) }\end{array}$ \\
\hline$M_{6}$ & Satın alma maliyetlerini düşürme & Fleischmann vd. (2003) \\
\hline$M_{7}$ & Tutulan stok miktarını azaltma & Biehl vd. (2007) \\
\hline$M_{8}$ & Nakliye masraflarını düşürme & Huscroft vd. (2013) \\
\hline$M_{9}$ & Ürün kalitesini arttırma & $\begin{array}{l}\text { Bernon vd. (2011) } \\
\text { Škapa ve Klapalová (2012) } \\
\text { Tibben-Lembke (2012) }\end{array}$ \\
\hline$M_{10}$ & Tedarik zinciri karbon ayak izini azaltma & $\begin{array}{l}\text { Fleischmann vd. (2003) } \\
\text { Bai ve Sarkis (2013) } \\
\text { Siva vd. (2013) }\end{array}$ \\
\hline
\end{tabular}




\section{ARAŞTIRMANIN KAPSAMI}

\subsection{Türkiye Elektrik-Elektronik Sektöründe Atık Yönetmeliği}

Elektrik elektronik sektörünün oluşturduğu atıklar "e-atık" olarak tanımlanmaktadır (AEEE Kontrolü Yönetmeliği, 2012). Öztürk (2015) yaptığı çalışmada Türkiye'de televizyon, çamaşır makinesi, buzdolabı ve klima kaynaklı e-atıkların yüzbinlerce ton demir, alüminyum, cam ve plastiğe eş değer olduğunu tespit etmiş; fakat bu çok büyük miktarda e-atığın 65-80\% oranında geri kazanımının mümkün olduğunu belirtmiştir. Aynı şekilde Öztürk (2015), Türkiye'de oluşacak on binlerce ton bilgisayar ve cep telefonu kaynaklı atığın geri kazanımının önemini bu ürünlerde bulunan değerli metallerin (altın, gümüş vb.) varlığına dikkat çekerek vurgulamıştır.

Yakın gelecekte e-atık miktarının hızı bir şekilde artış göstereceği ön görülmektedir. Özellikle, Türkiye'nin genç nüfusunun etkisi ile her geçen gün elektronik ürünlere olan talep artmaktadır. Ayrıca akıllı evler, akıllı otomobiller ve akıllı şehirler gibi kavramlar düşünüldüğünde diğer sektörlerin (otomotiv, inşaat vb.) elektronik ürünlere olan talepleri de artan oranlarda devam etmektedir. Türkiye'nin 10. Kalkınma Planı için yayınlanan elektronik grubu çalışma raporu (2015), elektronik sektörünün ihracatının 2023 yılında bugüne kıyasla 7 kat büyüyeceğini ön görmektedir. Tüm bu faktörler ve ön görüler, Türkiye'de elektronik sektörünün neden olduğu e-atık miktarının ciddi bir biçimde artacağını ve bu atıkların doğru ve etkin yönetiminin gittikçe önem kazanacağını göstermektedir.

Ömrünü tamamlamış elektrikli ve elektronik eşyalar "AEEE" olarak tanımlanmaktadır (Elday, 2015). 22.05.2012 tarihli resmi gazetede yayımlanan AEEE Yönetmeliği, e-atıkları 6 kategoriye ayırmaktadır: i) buzdolabı / soğutucular / iklimlendirme cihazları, ii) büyük beyaz eşyalar, iii) televizyon ve monitörler, iv) bilişim ve telekomünikasyon ve tüketici ekipmanları, v) aydınlatma ekipmanları, vi) küçük ev aletleri, elektrikli ve elektronik aletler, oyuncaklar, spor ve eğlence ekipmanları. Bu yönetmelik temel olarak AEEE üretiminde zararlı madde kullanımının azaltılmasını, e-atık oluşumunu engellemeyi ve bertaraf edilecek atık miktarının azaltılması için yeniden kullanım, geri dönüşüm, geri kazanım yöntem ve hedeflerine ilişkin esasları düzenlemektedir. Bu kapsamda, üreticilere AEEE'leri toplama, taşıma, geri kazanma gibi çeşitli tersine lojistik aktivitelerini yerine getirme mesuliye- tini vermektedir. Yönetmelik, AB direktifleri doğrultusunda toplanması gereken AEEE miktarını her geçen yıl $A B$ ülkeleri ile uyumlaştırarak arttırmaktadır.

\subsection{Vestel}

1984 yılında kurulan ve şu an Zorlu Holding bünyesinde faaliyet gösteren Vestel Şirketler Grubu geldiği pozisyon itibariyle dünyanın büyük teknoloji şirketlerinden biri olarak göze çarpmaktadır. Manisa'da 1 milyon metrekarenin üzerine kurduğu büyük üretim üssü, 16000 çalışanı ile günde 76000 ürün üretebilmektedir. Bu üretim düzeyi elektronik ürün grubunda uzun süredir Vestel'i Türkiye'de ihracat şampiyonu yaparken, Avrupa TV pazarında da 2'nci sırada yer almasını sağlamıştır. Vestel, tüketici elektroniği, beyaz eşya, dijital ürünler, bilgi teknolojileri, LED aydınlatma ve savunma alanlarında üretim yaparak çok geniş bir ürün yelpazesine sahip bulunmaktadır (Vestel Şirketler Grubu, 2016).

$\mathrm{Bu}$ araştırmanın elektrik-elektronik sektörü ürünlerinin tersine lojistik süreçlerini incelemesi ve Vestel'in de bu sektörde listelenen hemen hemen her ürünü üretmesi araştırma sonuçlarının sektör bazında genellenebilirlik seviyesini arttırmaktadır. Ayrıca Şikâyet Endeksi'nde son 3 yıldır Vestel'in Türkiye'de birinci sırada olması, tersine lojistik süreçlerine gerekli ehemmiyeti gösterdiğini kanıtlayarak bu araştırma için uygun bir örneklem olduğunu göstermektedir.

\section{ARAŞTIRMA YÖNTEMI}

Bu araştırmada, Warfield (1974) tarafından geliştirilen "yorumlayıcı yapısal modellemesi" yöntemi kullanılmıştır. İnteraktif bir yöntem olan "yorumlayıcı yapısal modelleme", analiz edilen çok sayıda faktörün birbirleri arasındaki kompleks ilişkiler yumağını ortaya çıkarabilmektedir (Janes, 1988). Bu yöntem ile incelenen faktörler arasındaki direk ilişkilerin yanı sıra, endirekt ilişkilerin de ortaya konabilmesi analize konu olan olgu hakkında çok daha iyi bir bilgiye sahip olunmasına olanak vermektedir (Attri vd., 2013). Tersine lojistik alanında yapılan çalışmalarda da "yorumlayıcı yapısal modellemesi" yönteminden faydalanılmıştır. Ravi ve Shankar (2005) tersine lojistik uygulamalarına engel olan bariyerler arasındaki ilişkileri bu yöntemle analiz ederken, Govindan vd. (2015) üçüncü parti tersine lojistik servis sağlayıcısı seçme probleminde "yorumlayıcı yapısal modellemesi" yöntemini kullanmıştır.

"Yorumlayıcı yapısal modellemesi" yönteminde izlenen adımlar Şekil 2'de gösterilmektedir: 


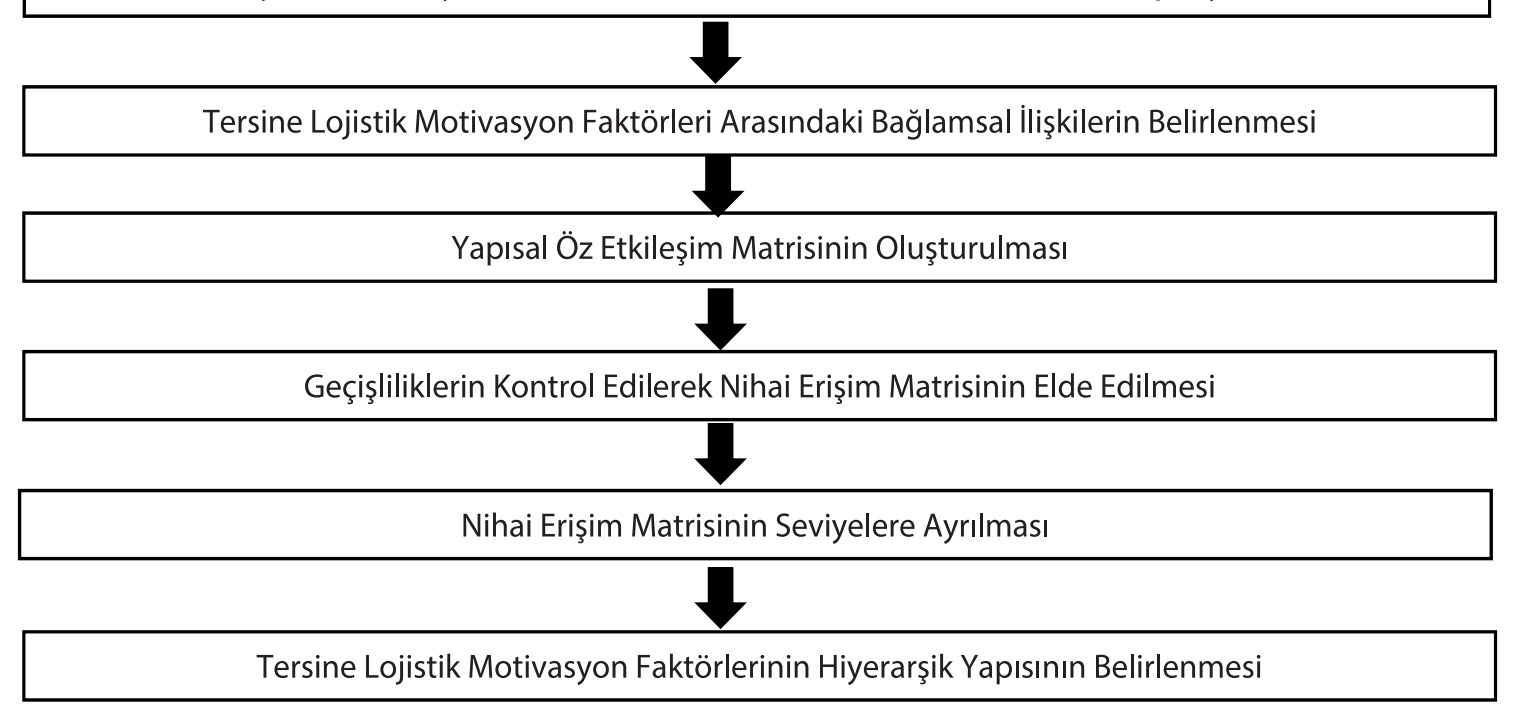

Şekil 2: Yorumlayıcı Yapısal Modellemesinin Akış Şeması

Yöntemin ilk aşamasında, yapılacak analizde dikkate alınacak motivasyonların belirlenmesi için etraflı bir literatür incelemesi yapılmıştır. Prestijli dergilerde yayınlanmış ve etkisi yüksek makaleler, motivasyonların belirlenmesinde kaynak olarak dikkate alınmıştır. Ayrıca bu aşamada çalışmaya katılan uzmanların görüşleri ve tavsiyeleri doğrultusunda literatür taraması şekillendirilmiştir. Örneğin Tablo 1'de dokuzuncu sırada listelenen "ürün kalitesinin arttırılması" motivasyon faktörü, toplantılara katılan yöneticilerin geri bildirimi ile literatürde araştııılmış ve akabinde listeye eklenmesine karar verilmiştir. Bu tarama sürecinin sonunda üreticileri tersine lojistik faaliyetlerine yönelten motivasyon faktörleri (Tablo 1 'de gösterildiği üzere) yorumlayıc yapısal modelleme analizinde kullanılmıştır.

Yöntemin ikinci aşaması olan tersine lojistik motivasyon faktörleri arasındaki bağlamsal ilişkilerin belirlenmesi için nominal grup tekniği kullanılmıştır. Nominal grup tekniğinde katılımcılar sorulan konu hakkındaki bireysel görüşlerini paylaşmaktadır. Daha sonra bu farklı görüşlerin yörüngesinde ilerleyen tartışmanın modere edilmesiyle konu hakkında konsensüse ulaşılmaktadır. Bu noktada zengin bir tartışma ortamı sağlamak için tersine lojistik süreçleri ile ilişkili ama bu süreçlere farklı noktalardan bakabilecek pozisyonda olan yöneticilerin görüşmelere katılımına özen gösterilmiştir. Bu doğrultuda görüşmeler, Müşteri Hizmetleri Genel Müdür Yardımcısı, Planlama Sorumlusu, Saha Operasyonları Destek Sorumlusu ve Teknik Ürün Sorumlusunun katılımlarıyla gerçekleşmiştir. Görüşmelerde her bir motivasyon faktör ikilisi için şu şeklide bir beyin fırtınası gerçekleştirilmiştir: "Motivasyon i'nin bağlantılı olduğu hedef tersine lojistik süreçlerinin katkısıyla gerçekleştirildiğinde motivasyon j'ye bağlı olan hedefin başarılmasına katkı sağlar mı?". Bu soru ekseninde her bir motivasyon faktör ikilisi için yapılan tartışmalar uzlaşıyla bir sonuca bağlanmış ve bu sonuçlar Tablo 2'de gösterilen 4 sembolden bir tanesi kullanılarak yapısal öz etkileşim matrisine kodlanmıştır:

Tablo 2: Yapısal Öz Etkileşim Matrisinin Oluşturulmasında Kullanılan Semboller ve Anlamları

\begin{tabular}{|l|l|}
\hline A & $\begin{array}{l}\text { Motivasyon i'ye bağlı olan hedef tersine lojistik süreçlerinin katkısıyla gerçekleştirildiğinde motivasyon j'nin bağlı } \\
\text { olduğu hedefin başarılmasına destek sağlar. }\end{array}$ \\
\hline $\mathbf{V}$ & $\begin{array}{l}\text { Motivasyon j'ye bağlı olan hedef tersine lojistik süreçlerinin katkısıyla gerçekleştirildiğinde motivasyon i'nin bağlı } \\
\text { olduğu hedefin başarılmasına destek sağlar. }\end{array}$ \\
\hline $\mathbf{X}$ & $\begin{array}{l}\text { Motivasyon i'ye bağlı olan hedef tersine lojistik süreçlerinin katkısıyla gerçekleştirildiğinde motivasyon j'nin bağlı } \\
\text { olduğu hedefin başarılmasına destek sağlarken aynı zamanda motivasyon j'ye bağlı olan hedef tersine lojistik } \\
\text { süreçlerinin katkısıyla gerçekleştirildiğinde motivasyon i'nin bağlı olduğu hedefin başarılmasına destek sağlar. }\end{array}$ \\
\hline $\mathbf{0}$ & Motivasyon i ve j'ye bağlı hedeflerin gerçekleştirilmesi birbirinden bağımsızdır. \\
\hline
\end{tabular}


Yapısal öz etkileşim matrisinde kodlanan A, V, X ve $O$ harfleri başlangıç erişim matrisine şu şekilde transfer edilmektedir:

- A harfi, yapısal öz etkileşim matrisinin üst satırında listelenen motivasyonun $\left(M_{i}\right)$ bu matrisin ilk sütununda listelenen motivasyonu $\left(M_{\mathrm{j}}\right)$ etkilediğini simgelemektedir. Dolayısıyla başlangıç erişim matrisine $A$ harfi $(i, j)=1,(j, i)=0$ olarak transfer edilmektedir.

- V harfi, yapısal öz etkileşim matrisinin üst satırında listelenen motivasyonun $\left(\mathrm{M}_{\mathrm{i}}\right)$ bu matrisin ilk sütununda listelenen motivasyondan $\left(\mathrm{M}_{\mathrm{j}}\right)$ etkilendiğini simgelemektedir. Dolayısıyla başlangıç erişim matrisine $V$ harfi $(\mathrm{i}, \mathrm{j})=0,(\mathrm{j}, \mathrm{i})=1$ olarak transfer edilmektedir.

- X harfi, yapısal öz etkileşim matrisinin üst satırında listelenen motivasyonun $\left(M_{i}\right)$ hem bu matrisin ilk sütununda listelenen motivasyonu $\left(M_{\mathrm{j}}\right)$ etkilediğini hem de bu ilk sütunda listelenen motivasyondan $\left(M_{j}\right)$ etkilendiğini simgelemektedir. Dolayısıyla başlangıç erişim matrisine $X$ harfi $(i, j)=1$, $(j, i)=1$ olarak transfer edilmektedir.

- O harfi, yapısal öz etkileşim matrisinin üst satırında listelenen motivasyonun $\left(M_{i}\right)$ bu matrisin ilk sütununda listelenen motivasyonla $\left(M_{j}\right)$ herhangi bir etkileşiminin olmadığını simgelemektedir. Dolayısıyla başlangıç erişim matrisine $O$ harfi $(i, j)=0,(j, i)=0$ olarak transfer edilmektedir.

Yukarıda belirtilen yöntemle yapısal öz etkileşim matrisinden başlangıç erişim matrisi elde edilmektedir. Daha sonra başlangıç erişim matrisinde mantıksal ilişki hatalarının olup olmadığı kontrol edilmektedir. Katılımcıların bir çok faktör arasındaki ikili ilişkiyi ayrı ayrı incelemesi faktörler arasındaki endirekt etkilerin görülebilmesini zorlaştırabilmekte ve dolayısıyla geçişlilik kuralının ihlal edilmesine sebep olabilmektedir. Geçişlilik kuralı basitçe şunu ön görmektedir: Eğer $A$ faktörünün $B$ faktörünü etkilediği ve $B$ faktörünün $C$ faktörünü etkilediği iddia ediliyorsa, $A$ faktörünün C faktörünü etkilediği kabul edilmelidir. Başlangıç erişim matrisinde bu kuralın ihlal edildiği durumlar bulunup düzeltilerek nihai erişim matrisi elde edilmektedir.

Analizin son aşamasında her bir faktörün hiyerarşik seviyesi tespit edilmektedir. Bunun için analiz edilen her bir faktörün erişebildiği faktörler kümesi ve bu her bir faktörü etkileyen öncül faktörler kümesi nihai erişim matrisinden bulunmaktadır. Eğer bu bulunan iki kümenin kesişim kümesi, söz konusu faktörlerin erişebildiği faktörler kümesi ile eşit ise hiyerarşinin en üst seviyesine (birinci seviyeye) yerleştirilmektedir. illk seviye tamamlandıktan sonra, ilk seviyeye yerleştirilen faktörler analizden çıkarılmaktadır. Elde kalan faktörlerin her birinin tekrar erişebildiği faktörlerin kümesi ve bu her bir faktörü etkileyen öncül faktörler kümesi bulunarak kesişim kümeleri bulunmaktadır. Yine aynı şekilde, erişebildiği faktörlerin kümesi ile kesişim kümesi eşit olan faktörler hiyerarşide ikinci seviyeye yerleştirilmektedir. Bu akış, analiz edilen tüm faktörlerin hiyerarşik seviyeleri belirleninceye kadar devam etmektedir.

\section{YÖNTEMIN UYGULANMASI}

Çalışmanın daha önceki bölümlerinde belirtildiği üzere tersine lojistik motivasyon faktörlerinin hiyerarşisi hem Vestel'in faaliyet gösterdiği bağlam dikkate alınarak hem de bu bağlamdan bağımsız olarak kuramsal çerçevede ayrı ayrı oluşturulmuştur. Dolayısıyla her bir hiyerarşinin belirlenmesi için firma yöneticileriyle ayrı zamanlarda görüşmeler düzenlenmiştir. İlk görüşme öncesinde, toplantı katılımcılarına yapılan araştırmanın amacı aktarılmış ve bu amacın gerçekleştirilmesi için izlenecek yöntem hakkında bilgi verilmiştir. Bu kapsamda literatür araştırmasına dayalı olarak ortaya çıkarılmış olan tersine lojistik motivasyon faktörleri (Tablo 1) açıklanarak izah edilmiştir. Bu aşamadan sonra uygulamaya geçilmiş ve tersine lojistik motivasyon faktörleri arasındaki ilişkiler Vestel'in faaliyet bağlamı düşünülerek analiz edilmiştir. Katılımcılar her bir motivasyon ikilisi için görüşlerini ortaya koymuş ve mutabakat sağlanıncaya kadar katıımcıların tartışmaları modere edilmiştir. İlk görüşmenin tamamlanması (yapısal öz etkileşim matrisinin doldurulması) yaklaşık 3-4 saat zaman almıştır. Bir sonraki haftada yapılan ikinci görüşmede ise firmanın faaliyet bağlamından bağımsız olarak motivasyon faktörleri arasındaki ilişkiler kuramsal çerçevede incelenmiştir. Katılımcıların bir önceki haftadan metodolojiye aşina olmaları süreci hızlandırmış ve motivasyon faktörleri arasındaki karşılaştırmaların yapılması (yapısal öz etkileşim matrisinin doldurulması) yaklaşık 2 saatte tamamlanmıştır.

$\mathrm{Bu}$ bölümün ilerleyen kısımlarında "yorumlayıcı yapısal modelleme" yönteminin adımları, yapılan 2 farklı uygulama için ayrı ayrı gösterilecektir.

\subsection{Vestel Firması Üzerinde Yapılan Analizin Sonuçları}

Vestel'in faaliyet bağlamının dikkate alınarak tersine lojistik motivasyon faktörleri arasındaki ilişki- 
lerin ikili olarak değerlendirildiği yapısal öz etkileşim matrisi Tablo 3'de gösterilmektedir. Mevcut koşullarda tersine lojistik aktiviteleri için devletin herhangi bir teşvik ve desteğinin olmadığını katılımcılar ilk görüşmeye başlamadan önce belirtmiştir. Ayrıca, şu an tersine lojistik faaliyetlerinin satın alma maliyetlerini düşürecek kadar gelişmişlik seviyesine ulaşmadığını da not etmişlerdir. Katılımcıların bu görüş ve önerileri dikkate alınarak devlet teşvik ve desteklerinden yararlanma (M5) ve satın alma maliyetlerini düşürme (M6) tersine lojistik motivasyon faktörleri Vestel'in faaliyet bağlamının dikkate alındığı analizden çıkarılmıştır.

Tablo 4, öz etkileşim matrisindeki harf kodlamalarının 0 veya 1'e çevrilmesi sonucu oluşan başlangıç erişim matrisini göstermektedir. Bu matris incelendiğinde, kanuni yükümlülükleri yerine getirme (M4) motivasyon faktörünün diğer dört motivasyon faktörünü direk etkilediği fakat hiçbir faktörden direk etkilenmediği gözükmektedir. Tekrar satın alma davranışını besleme (M1) ve nakliye masraflarını düşürme (M8) motivasyon faktörlerinin ise diğer beş motivasyon faktöründen direk olarak etkilenmesi dikkat çekmektedir.

Tablo 5, geçişlilik kuralı ihlallerinin giderilerek endirekt ilişkilerin eklendiği nihai erişim matrisini göstermektedir. Bu matris incelendiğinde, kanuni yükümlülükleri yerine getirme $\left(M_{4}\right)$ motivasyon faktörünün direk veya dolaylı olarak tüm diğer motivasyon faktörlerini etkilediği gözükmektedir. Ayrıca dolaylı etkiler dikkate alındığında, finansal fırsatlardan yararlanma $\left(\mathrm{M}_{3}\right)$ motivasyon faktörünün diğer tüm motivasyon faktörlerinden etkilendiği tespit edilmiştir.

Tablo 3: Yapısal Öz Etkileşim Matrisi - Vestel'in Faaliyet Bağlamı

\begin{tabular}{|c|c|c|c|c|c|c|c|c|c|}
\hline & $\mathbf{M}_{\mathbf{2}}$ & $\mathbf{M}_{\mathbf{3}}$ & $\mathbf{M}_{\mathbf{4}}$ & $\mathbf{M}_{\mathbf{5}}$ & $\mathbf{M}_{\mathbf{6}}$ & $\mathbf{M}_{\mathbf{7}}$ & $\mathbf{M}_{\mathbf{8}}$ & $\mathbf{M}_{\mathbf{9}}$ & $\mathbf{M}_{\mathbf{1 0}}$ \\
\hline $\mathbf{M}_{\mathbf{1}}$ & $\mathrm{A}$ & $\mathrm{O}$ & $\mathrm{A}$ & $\mathrm{O}$ & $\mathrm{O}$ & $\mathrm{O}$ & $\mathrm{X}$ & $\mathrm{X}$ & $\mathrm{A}$ \\
\hline $\mathbf{M}_{\mathbf{2}}$ & & $\mathrm{O}$ & $\mathrm{A}$ & $\mathrm{O}$ & $\mathrm{O}$ & $\mathrm{O}$ & $\mathrm{O}$ & $\mathrm{X}$ & $\mathrm{A}$ \\
\hline $\mathbf{M}_{\mathbf{3}}$ & & & $\mathrm{O}$ & $\mathrm{O}$ & $\mathrm{O}$ & $\mathrm{O}$ & $\mathrm{A}$ & $\mathrm{A}$ & $\mathrm{O}$ \\
\hline $\mathbf{M}_{\mathbf{4}}$ & & & & 0 & $\mathrm{O}$ & $\mathrm{O}$ & $\mathrm{V}$ & $\mathrm{O}$ & $\mathrm{V}$ \\
\hline $\mathbf{M}_{\mathbf{5}}$ & & & & & $\mathrm{O}$ & $\mathrm{O}$ & $\mathrm{O}$ & $\mathrm{O}$ & $\mathrm{O}$ \\
\hline $\mathbf{M}_{\mathbf{6}}$ & & & & & & $\mathrm{O}$ & $\mathrm{O}$ & $\mathrm{O}$ & $\mathrm{O}$ \\
\hline $\mathbf{M}_{\mathbf{7}}$ & & & & & & & $\mathrm{X}$ & $\mathrm{A}$ & $\mathrm{O}$ \\
\hline $\mathbf{M}_{\mathbf{8}}$ & & & & & & & & $\mathrm{A}$ & $\mathrm{X}$ \\
\hline $\mathbf{M}_{\mathbf{9}}$ & & & & & & & & & $\mathrm{V}$ \\
\hline
\end{tabular}

Tablo 4: Başlangıç Erişim Matrisi - Vestel'in Faaliyet Bağlamı

\begin{tabular}{|c|c|c|c|c|c|c|c|c|c|c|}
\hline & $\mathbf{M}_{\mathbf{1}}$ & $\mathbf{M}_{\mathbf{2}}$ & $\mathbf{M}_{\mathbf{3}}$ & $\mathbf{M}_{\mathbf{4}}$ & $\mathbf{M}_{\mathbf{5}}$ & $\mathbf{M}_{\mathbf{6}}$ & $\mathbf{M}_{\mathbf{7}}$ & $\mathbf{M}_{\mathbf{8}}$ & $\mathbf{M}_{\mathbf{9}}$ & $\mathbf{M}_{\mathbf{1 0}}$ \\
\hline $\mathbf{M}_{\mathbf{1}}$ & 1 & 1 & 0 & 1 & 0 & 0 & 0 & 1 & 1 & 1 \\
\hline $\mathbf{M}_{\mathbf{2}}$ & 0 & 1 & 0 & 1 & 0 & 0 & 0 & 0 & 1 & 1 \\
\hline $\mathbf{M}_{\mathbf{3}}$ & 0 & 0 & 1 & 0 & 0 & 0 & 0 & 1 & 1 & 0 \\
\hline $\mathbf{M}_{\mathbf{4}}$ & 0 & 0 & 0 & 1 & 0 & 0 & 0 & 0 & 0 & 0 \\
\hline $\mathbf{M}_{\mathbf{5}}$ & 0 & 0 & 0 & 0 & 0 & 0 & 0 & 0 & 0 & 0 \\
\hline $\mathbf{M}_{\mathbf{6}}$ & 0 & 0 & 0 & 0 & 0 & 0 & 0 & 0 & 0 & 0 \\
\hline $\mathbf{M}_{\mathbf{7}}$ & 0 & 0 & 0 & 0 & 0 & 0 & 1 & 1 & 1 & 0 \\
\hline $\mathbf{M}_{\mathbf{8}}$ & 1 & 0 & 0 & 1 & 0 & 0 & 1 & 1 & 1 & 1 \\
\hline $\mathbf{M}_{\mathbf{9}}$ & 1 & 1 & 0 & 0 & 0 & 0 & 0 & 0 & 1 & 0 \\
\hline $\mathbf{M}_{\mathbf{1 0}}$ & 0 & 0 & 0 & 1 & 0 & 0 & 0 & 1 & 1 & 1 \\
\hline
\end{tabular}


Tablo 5: Nihai Erişim Matrisi - Vestel'in Faaliyet Bağlamı

\begin{tabular}{|c|c|c|c|c|c|c|c|c|c|c|}
\hline & $M_{1}$ & $M_{2}$ & $M_{3}$ & $M_{4}$ & $M_{5}$ & $M_{6}$ & $M_{7}$ & $M_{8}$ & $M_{9}$ & $M_{10}$ \\
\hline$M_{1}$ & 1 & 1 & 0 & 1 & 0 & 0 & $1^{*}$ & 1 & 1 & 1 \\
\hline$M_{2}$ & $1^{*}$ & 1 & 0 & 1 & 0 & 0 & $1^{*}$ & $1^{*}$ & 1 & 1 \\
\hline$M_{3}$ & $1^{*}$ & $1^{*}$ & 1 & $1^{*}$ & 0 & 0 & $1^{*}$ & 1 & 1 & $1^{*}$ \\
\hline$M_{4}$ & 0 & 0 & 0 & 1 & 0 & 0 & 0 & 0 & 0 & 0 \\
\hline$M_{5}$ & 0 & 0 & 0 & 0 & 0 & 0 & 0 & 0 & 0 & 0 \\
\hline$M_{6}$ & 0 & 0 & 0 & 0 & 0 & 0 & 0 & 0 & 0 & 0 \\
\hline$M_{7}$ & $1^{*}$ & $1^{*}$ & 0 & $1^{*}$ & 0 & 0 & 1 & 1 & 1 & $1^{*}$ \\
\hline$M_{8}$ & 1 & $1^{*}$ & 0 & 1 & 0 & 0 & 1 & 1 & 1 & 1 \\
\hline$M_{9}$ & 1 & 1 & 0 & $1^{*}$ & 0 & 0 & $1^{*}$ & $1^{*}$ & 1 & $1^{*}$ \\
\hline$M_{10}$ & $1^{*}$ & $1^{*}$ & 0 & 1 & 0 & 0 & 1 & 1 & 1 & 1 \\
\hline
\end{tabular}

Tablo 6, Vestel'in faaliyet bağlamının dikkate alınarak analiz edilen tersine lojistik motivasyon faktörlerinin hiyerarşik seviyelerinin belirlenme sürecini göstermektedir. Yorumlayıc yapısal modellemesi yönteminin uygulanması sonucunda kanuni yükümlülükleri yerine getirme $\left(M_{4}\right)$ motivasyon faktörü hi- yerarşinin en alt seviyesinde (3. seviyede) yer alırken, finansal firsatlardan yararlanma $\left(M_{3}\right)$ motivasyon faktörü hiyerarşinin en üst seviyesinde (1. seviyede) yer almıştır. Diğer incelenen altı motivasyon faktörünün ise hiyerarşinin orta seviyesinde (2. seviyede) yer aldığı tespit edilmiştir.

Tablo 6: Tersine Lojistik Motivasyon Faktörlerinin Hiyerarşik Seviyelerinin Belirlenmesi - Vestel'in Faaliyet Bağlamı

\begin{tabular}{|c|c|c|c|c|c|}
\hline $\begin{array}{l}\text { İterasyon } \\
\text { No. }\end{array}$ & $\begin{array}{l}\text { Tersine Lojistik } \\
\text { Motivasyon } \\
\left(\mathrm{M}_{\mathrm{i}}\right)\end{array}$ & $\begin{array}{l}M_{i}^{\prime} \text { 'nin Eriştiği } \\
\text { Motivasyon Kümesi }\end{array}$ & $\begin{array}{l}M_{i}^{\prime} \text { 'ye Erişen } \\
\text { Motivasyon Kümesi }\end{array}$ & $\begin{array}{l}\text { Kesişim } \\
\text { Kümesi }\end{array}$ & Seviye \\
\hline \multirow{8}{*}{1} & $M_{1}$ & $M_{1}, M_{2}, M_{3,} M_{7,} M_{8,} M_{9,} M_{10}$ & $M_{1}, M_{2}, M_{4,} M_{7}, M_{8,} M_{9}, M_{10}$ & $M_{1}, M_{2}, M_{7}, M_{8}, M_{9}, M_{10}$ & \\
\hline & $\mathrm{M}_{2}$ & $M_{1}, M_{2}, M_{3,} M_{7}, M_{8,} M_{9}, M_{10}$ & $M_{1}, M_{2}, M_{4}, M_{7}, M_{8,} M_{9}, M_{10}$ & $M_{1}, M_{2}, M_{7}, M_{8}, M_{9}, M_{10}$ & \\
\hline & $\mathrm{M}_{3}$ & $\mathrm{M}_{3}$ & $M_{1,} M_{2,} M_{3,} M_{4,} M_{7,} M_{8,} M_{9,} M_{10}$ & $\mathrm{M}_{3}$ & I \\
\hline & $\mathrm{M}_{4}$ & $M_{1,} M_{2,} M_{3,} M_{4,} M_{7}, M_{8,} M_{9,} M_{10}$ & $\mathrm{M}_{4}$ & $\mathrm{M}_{4}$ & \\
\hline & $\mathrm{M}_{7}$ & $M_{1}, M_{2}, M_{3}, M_{7}, M_{8}, M_{9}, M_{10}$ & $M_{1}, M_{2}, M_{4}, M_{7}, M_{8}, M_{9}, M_{10}$ & $M_{1}, M_{2}, M_{7}, M_{8}, M_{9}, M_{10}$ & \\
\hline & $M_{8}$ & $M_{1}, M_{2}, M_{3,} M_{7,} M_{8,} M_{9,} M_{10}$ & $M_{1}, M_{2}, M_{4}, M_{7}, M_{8,} M_{9}, M_{10}$ & $M_{1}, M_{2}, M_{7}, M_{8}, M_{9}, M_{10}$ & \\
\hline & $\mathrm{M}_{9}$ & $M_{1}, M_{2}, M_{3}, M_{7}, M_{8}, M_{9}, M_{10}$ & $M_{1}, M_{2}, M_{4}, M_{7}, M_{8,}, M_{9}, M_{10}$ & $M_{1}, M_{2}, M_{7}, M_{8}, M_{9}, M_{10}$ & \\
\hline & $M_{10}$ & $M_{1}, M_{2}, M_{3,} M_{7}, M_{8,} M_{9}, M_{10}$ & $M_{1}, M_{2}, M_{4}, M_{7}, M_{8,} M_{9}, M_{10}$ & $M_{1}, M_{2}, M_{7}, M_{8}, M_{9}, M_{10}$ & \\
\hline \multirow{7}{*}{2} & $\mathrm{M}_{1}$ & $M_{1}, M_{2}, M_{7}, M_{8,} M_{9}, M_{10}$ & $M_{1}, M_{2}, M_{7}, M_{8}, M_{9}, M_{10}$ & $M_{1}, M_{2}, M_{7}, M_{8}, M_{9}, M_{10}$ & II \\
\hline & $\mathrm{M}_{2}$ & $M_{1}, M_{2,} M_{7,} M_{8,} M_{9,} M_{10}$ & $M_{1}, M_{2,} M_{7}, M_{8,} M_{9}, M_{10}$ & $M_{1}, M_{2}, M_{7}, M_{8}, M_{9}, M_{10}$ & II \\
\hline & $\mathrm{M}_{4}$ & $M_{1}, M_{2,} M_{4,} M_{7}, M_{8,} M_{9}, M_{10}$ & $\mathrm{M}_{4}$ & $\mathrm{M}_{4}$ & \\
\hline & $M_{7}$ & $M_{1}, M_{2,} M_{7,} M_{8,} M_{9,} M_{10}$ & $M_{1,} M_{2,} M_{7}, M_{8,} M_{9} M_{10}$ & $M_{1}, M_{2}, M_{7}, M_{8}, M_{9}, M_{10}$ & II \\
\hline & $M_{8}$ & $M_{1}, M_{2}, M_{7}, M_{8}, M_{9}, M_{10}$ & $M_{1}, M_{2}, M_{7}, M_{8}, M_{9}, M_{10}$ & $M_{1}, M_{2}, M_{7}, M_{8}, M_{9}, M_{10}$ & II \\
\hline & $\mathrm{M}_{9}$ & $M_{1}, M_{2}, M_{7}, M_{8}, M_{9}, M_{10}$ & $M_{1}, M_{2}, M_{7}, M_{8,} M_{9}, M_{10}$ & $M_{1}, M_{2}, M_{7}, M_{8}, M_{9}, M_{10}$ & II \\
\hline & $\mathrm{M}_{10}$ & $M_{1}, M_{2,} M_{7,} M_{8,} M_{9,} M_{10}$ & $M_{1}, M_{2,} M_{7,} M_{8,} M_{9,} M_{10}$ & $M_{1}, M_{2}, M_{7}, M_{8}, M_{9}, M_{10}$ & II \\
\hline 3 & $\mathrm{M}_{4}$ & $\mathrm{M}_{4}$ & $\mathrm{M}_{4}$ & $\mathrm{M}_{4}$ & III \\
\hline
\end{tabular}




\subsection{Kuramsal Analizin Sonuçları}

Vestel'in faaliyet bağlamından bağımsız olarak tersine lojistik motivasyon faktörleri arasındaki ilişkilerin kuramsal çerçevede değerlendirildiği öz etkileşim matrisi Tablo 7'de gösterilmektedir. Katılımcılar, her bir motivasyona bağlı olan tersine lojistik aktivitelerinin sağladığı katkının var olduğunu varsayarak 10 motivasyon faktörü arasındaki ikili ilişkileri analiz etmiştir. Örneğin, Türkiye'de şu an tersine lojistik uygulaması için bir devlet teşviki olmamasına rağmen "eğer böyle bir teşvik olsaydı diğer motivasyon faktörleri nasıl etkilenirdi?" veya "firmaların değerli metalleri çıkarmak için gerekli ekipmanı olsaydı, bu durumun diğer motivasyon faktörlerine bağlı hedefler ile etki- leşimi nasıl olurdu?" sorularına katılımcılar kuramsal bir yaklaşımla cevap vermiştir.

Tablo 8, öz etkileşim matrisindeki harf kodlamalarının 0 veya 1'e çevrilmesi sonucu oluşan başlangıç erişim matrisini göstermektedir. Tablo 8 incelendiğinde, ürün kalitesini arttırma (M9) motivasyon faktörünün diğer altı motivasyon faktörünü direk etkilediği fakat hiçbir faktörden direk etkilenmediği dikkat çekmektedir. Tekrar satın alma davranışını besleme (M1) motivasyon faktörünün ise tutulan stok miktarını azaltma (M7) motivasyon faktörü hariç diğer tüm motivasyon faktörlerinden etkilendiği gözükmektedir.

Tablo 7: Yapısal Öz Etkileşim Matrisi - Kuramsal Çerçevede Analiz

\begin{tabular}{|c|c|c|c|c|c|c|c|c|c|}
\hline & $\mathbf{M}_{2}$ & $\mathbf{M}_{3}$ & $\mathbf{M}_{4}$ & $\mathbf{M}_{5}$ & $\mathbf{M}_{6}$ & $\mathbf{M}_{\mathbf{7}}$ & $\mathbf{M}_{8}$ & $\mathbf{M}_{9}$ & $\mathbf{M}_{10}$ \\
\hline $\mathbf{M}_{1}$ & $\mathrm{~A}$ & $\mathrm{X}$ & $\mathrm{X}$ & $\mathrm{A}$ & $\mathrm{A}$ & $\mathrm{V}$ & $\mathrm{A}$ & $\mathrm{A}$ & $\mathrm{A}$ \\
\hline $\mathbf{M}_{2}$ & & $\mathrm{X}$ & $\mathrm{O}$ & $\mathrm{O}$ & $\mathrm{O}$ & $\mathrm{O}$ & $\mathrm{O}$ & $\mathrm{A}$ & $\mathrm{A}$ \\
\hline $\mathbf{M}_{3}$ & & & $\mathrm{~A}$ & $\mathrm{O}$ & $\mathrm{V}$ & $\mathrm{V}$ & $\mathrm{A}$ & $\mathrm{A}$ & $\mathrm{O}$ \\
\hline $\mathbf{M}_{\mathbf{4}}$ & & & & $\mathrm{X}$ & $\mathrm{O}$ & $\mathrm{O}$ & $\mathrm{O}$ & $\mathrm{O}$ & $\mathrm{V}$ \\
\hline $\mathbf{M}_{5}$ & & & & & $\mathrm{O}$ & $\mathrm{O}$ & $\mathrm{O}$ & $\mathrm{O}$ & $\mathrm{O}$ \\
\hline $\mathbf{M}_{\mathbf{6}}$ & & & & & & $\mathrm{V}$ & $\mathrm{V}$ & $\mathrm{O}$ & $\mathrm{V}$ \\
\hline $\mathbf{M}_{\mathbf{7}}$ & & & & & & & $\mathrm{O}$ & $\mathrm{A}$ & $\mathrm{V}$ \\
\hline $\mathbf{M}_{\mathbf{8}}$ & & & & & & & & $\mathrm{A}$ & $\mathrm{V}$ \\
\hline $\mathbf{M}_{9}$ & & & & & & & & & $\mathrm{~V}$ \\
\hline
\end{tabular}

Tablo 8: Başlangıç Erişim Matrisi - Kuramsal Çerçevede Analiz

\begin{tabular}{|l|c|c|c|c|c|c|c|c|c|c|}
\hline & $\mathbf{M}_{\mathbf{1}}$ & $\mathbf{M}_{\mathbf{2}}$ & $\mathbf{M}_{\mathbf{3}}$ & $\mathbf{M}_{\mathbf{4}}$ & $\mathbf{M}_{\mathbf{5}}$ & $\mathbf{M}_{\mathbf{6}}$ & $\mathbf{M}_{\mathbf{7}}$ & $\mathbf{M}_{\mathbf{8}}$ & $\mathbf{M}_{\mathbf{9}}$ & $\mathbf{M}_{\mathbf{1 0}}$ \\
\hline $\mathbf{M}_{\mathbf{1}}$ & 1 & 1 & 1 & 1 & 1 & 1 & 0 & 1 & 1 & 1 \\
\hline $\mathbf{M}_{\mathbf{2}}$ & 0 & 1 & 1 & 0 & 0 & 0 & 0 & 0 & 1 & 1 \\
\hline $\mathbf{M}_{\mathbf{3}}$ & 1 & 1 & 1 & 1 & 0 & 0 & 0 & 1 & 1 & 0 \\
\hline $\mathbf{M}_{\mathbf{4}}$ & 1 & 0 & 0 & 1 & 1 & 0 & 0 & 0 & 0 & 0 \\
\hline $\mathbf{M}_{\mathbf{5}}$ & 0 & 0 & 0 & 1 & 1 & 0 & 0 & 0 & 0 & 0 \\
\hline $\mathbf{M}_{\mathbf{6}}$ & 0 & 0 & 1 & 0 & 0 & 1 & 0 & 0 & 0 & 0 \\
\hline $\mathbf{M}_{\mathbf{7}}$ & 1 & 0 & 1 & 0 & 0 & 1 & 1 & 0 & 1 & 0 \\
\hline $\mathbf{M}_{\mathbf{8}}$ & 0 & 0 & 0 & 0 & 0 & 1 & 0 & 1 & 1 & 0 \\
\hline $\mathbf{M}_{9}$ & 0 & 0 & 0 & 0 & 0 & 0 & 0 & 0 & 1 & 0 \\
\hline $\mathbf{M}_{\mathbf{1 0}}$ & 0 & 0 & 0 & 1 & 0 & 1 & 1 & 1 & 1 \\
\hline
\end{tabular}


Tablo 9, geçişlilik kuralı ihlallerinin giderilerek endirekt ilişkilerin eklendiği nihai erişim matrisini göstermektedir. Dolaylı etkilerin de dikkate alındığı Tablo 9 incelendiğinde, ürün kalitesini arttırma (M9) motivasyon faktörü hariç diğer tüm motivasyon faktörlerinin birbirlerini etkiledikleri tespit edilmiştir. Dolaylı etkiler göz önünde bulundurulması durumunda da, ürün kalitesini arttırma (M9) motivasyon faktörünün yine diğer hiçbir motivasyon faktöründen etkilenmediği saptanmıştır.
Tablo 10, kuramsal çerçevede analiz edilen tersine lojistik motivasyon faktörlerinin hiyerarşik seviyelerinin belirlenme sürecini göstermektedir. Yorumlayıcı yapısal modellemesi yönteminin uygulanması sonucunda ürün kalitesini arttırma $\left(M_{9}\right)$ motivasyon faktörü hiyerarşinin alt seviyesinde (2. seviyede) yer alırken, diğer incelenen dokuz motivasyon faktörünün ise hiyerarşinin bir üst seviyesinde (1. seviyede) yer aldığı tespit edilmiştir.

Tablo 9: Nihai Erişim Matrisi - Kuramsal Çerçevede Analiz

\begin{tabular}{|c|c|c|c|c|c|c|c|c|c|c|}
\hline & $M_{1}$ & $M_{2}$ & $M_{3}$ & $M_{4}$ & $M_{5}$ & $M_{6}$ & $M_{7}$ & $M_{8}$ & $M_{9}$ & $M_{10}$ \\
\hline$M_{1}$ & 1 & 1 & 1 & 1 & 1 & 1 & $1^{*}$ & 1 & 1 & 1 \\
\hline$M_{2}$ & $1^{*}$ & 1 & 1 & $1^{*}$ & $1^{*}$ & $1^{*}$ & $1^{*}$ & $1^{*}$ & 1 & 1 \\
\hline$M_{3}$ & 1 & 1 & 1 & 1 & $1^{*}$ & $1 *$ & $1^{*}$ & 1 & 1 & $1^{*}$ \\
\hline$M_{4}$ & 1 & $1^{*}$ & $1^{*}$ & 1 & 1 & $1^{*}$ & $1^{*}$ & $1^{*}$ & $1^{*}$ & $1^{*}$ \\
\hline$M_{5}$ & $1^{*}$ & $1^{*}$ & $1^{*}$ & 1 & 1 & $1^{*}$ & $1^{*}$ & $1^{*}$ & $1 *$ & $1^{*}$ \\
\hline$M_{6}$ & $1^{*}$ & $1^{*}$ & 1 & $1^{*}$ & $1^{*}$ & 1 & $1^{*}$ & $1^{*}$ & $1^{*}$ & $1^{*}$ \\
\hline$M_{7}$ & 1 & $1^{*}$ & 1 & $1^{*}$ & $1^{*}$ & 1 & 1 & $1^{*}$ & 1 & $1^{*}$ \\
\hline$M_{8}$ & $1^{*}$ & $1^{*}$ & $1^{*}$ & $1^{*}$ & $1^{*}$ & 1 & $1^{*}$ & 1 & 1 & $1^{*}$ \\
\hline$M_{9}$ & 0 & 0 & 0 & 0 & 0 & 0 & 0 & 0 & 1 & 0 \\
\hline$M_{10}$ & $1^{*}$ & $1^{*}$ & $1^{*}$ & 1 & $1^{*}$ & 1 & 1 & 1 & 1 & 1 \\
\hline
\end{tabular}

Tablo 10: Tersine Lojistik Motivasyon Faktörlerinin Hiyerarşik Seviyelerinin Belirlenmesi - Kuramsal Çerçevede Analiz

\begin{tabular}{|c|c|c|c|c|c|}
\hline $\begin{array}{l}\text { İterasyon } \\
\text { No. }\end{array}$ & $\begin{array}{l}\text { Tersine Lojistik } \\
\text { Motivasyonu }\left(\mathrm{M}_{\mathrm{i}}\right)\end{array}$ & $\begin{array}{l}\text { M,'nin Eriştiği } \\
\text { Motivasyon Kümesi }\end{array}$ & $\begin{array}{l}M_{i}^{\prime} \text { ye Erişen } \\
\text { Motivasyon Kümesi }\end{array}$ & $\begin{array}{l}\text { Kesişim } \\
\text { Kümesi }\end{array}$ & Seviye \\
\hline \multirow{10}{*}{1} & $M_{1}$ & $\begin{array}{l}M_{1,} M_{2,} M_{3,} M_{4,} M_{5}, M_{6,} M_{7,} \\
M_{8,} M_{10}\end{array}$ & $\begin{array}{l}M_{1,} M_{2,} M_{3,} M_{4,} M_{5,} M_{6,} M_{7,} M_{8,} M_{9} \\
M_{10}\end{array}$ & $\begin{array}{l}M_{1,} M_{2,} M_{3,} M_{4,} M_{5,} M_{6,} \\
M_{7,} M_{8,} M_{10}\end{array}$ & I \\
\hline & $M_{2}$ & $\begin{array}{l}M_{1,} M_{2,} M_{3,} M_{4,} M_{5,} M_{6,} M_{7,} \\
M_{8,} M_{10}\end{array}$ & $\begin{array}{l}M_{1,} M_{2,} M_{3,} M_{4,} M_{5,} M_{6,} M_{7,} M_{8,} M_{9} \\
M_{10}\end{array}$ & $\begin{array}{l}M_{1,} M_{2,} M_{3,} M_{4,} M_{5,} M_{6,} \\
M_{7,} M_{8,} M_{10}\end{array}$ & I \\
\hline & $M_{3}$ & $\begin{array}{l}M_{1,} M_{2,} M_{3,} M_{4,} M_{5,} M_{6,} M_{7,} \\
M_{8,} M_{10}\end{array}$ & $\begin{array}{l}M_{1,} M_{2,} M_{3,} M_{4,} M_{5}, M_{6,} M_{7,} M_{8,} M_{9} \\
M_{10}\end{array}$ & $\begin{array}{l}M_{1,} M_{2,} M_{3,} M_{4,} M_{5,} M_{6,} \\
M_{7} M_{8,} M_{10}\end{array}$ & I \\
\hline & $M_{4}$ & $\begin{array}{l}M_{1,} M_{2,} M_{3,} M_{4,} M_{5,} M_{6,} M_{7,} \\
M_{8,} M_{10}\end{array}$ & $\begin{array}{l}M_{1,}, M_{2,} M_{3,} M_{4,} M_{5,} M_{6,} M_{7,} M_{8,} M_{9} \\
M_{10}\end{array}$ & $\begin{array}{l}M_{1,} M_{2,} M_{3,} M_{4,} M_{5,} M_{6,} \\
M_{7} M_{8,} M_{10}\end{array}$ & I \\
\hline & $M_{5}$ & $\begin{array}{l}M_{1,} M_{2,} M_{3,} M_{4,} M_{5,} M_{6,} M_{7,} \\
M_{8,} M_{10}\end{array}$ & $\begin{array}{l}M_{1,} M_{2,} M_{3,} M_{4,} M_{5}, M_{6,} M_{7}, M_{8,} M_{9} \\
M_{10}\end{array}$ & $\begin{array}{l}M_{1,} M_{2,} M_{3,} M_{4,} M_{5}, M_{6,} \\
M_{7,} M_{8,} M_{10}\end{array}$ & I \\
\hline & $M_{6}$ & $\begin{array}{l}M_{1,} M_{2,} M_{3,} M_{4,} M_{5,} M_{6,} M_{7,} \\
M_{8,} M_{10}\end{array}$ & $\begin{array}{l}M_{1,} M_{2,} M_{3}, M_{4,} M_{5}, M_{6,} M_{7,} M_{8,} M_{9} \\
M_{10}\end{array}$ & $\begin{array}{l}M_{1,} M_{2,} M_{3,} M_{4,} M_{5,} M_{6,} \\
M_{7,} M_{8,} M_{10}\end{array}$ & I \\
\hline & $M_{7}$ & $\begin{array}{l}M_{1,} M_{2,} M_{3,} M_{4,} M_{5,} M_{6,} M_{7,} \\
M_{8,} M_{10}\end{array}$ & $\begin{array}{l}M_{1,}, M_{2,} M_{3,} M_{4,} M_{5}, M_{6,} M_{7,} M_{8,} M_{9} \\
M_{10}\end{array}$ & $\begin{array}{l}M_{1,} M_{2,} M_{3,} M_{4,} M_{5,} M_{6,} \\
M_{7} M_{8,} M_{10}\end{array}$ & I \\
\hline & $M_{8}$ & $\begin{array}{l}M_{1,} M_{2,} M_{3,} M_{4,} M_{5,} M_{6,} M_{7,} \\
M_{8,} M_{10}\end{array}$ & $\begin{array}{l}M_{1,}, M_{2,} M_{3,} M_{4,} M_{5}, M_{6,} M_{7,} M_{8,} M_{9} \\
M_{10}\end{array}$ & $\begin{array}{l}M_{1,} M_{2,} M_{3,} M_{4,} M_{5,} M_{6,} \\
M_{7} M_{8,} M_{10}\end{array}$ & I \\
\hline & $\mathrm{M}_{9}$ & $\begin{array}{l}M_{1,} M_{2,} M_{3,} M_{4,} M_{5,} M_{6,} M_{7,} \\
M_{8,} M_{2,} M_{10}\end{array}$ & $M_{9}$ & $M_{9}$ & \\
\hline & $M_{10}$ & $\begin{array}{l}M_{1,} M_{2,} M_{3,} M_{4,} M_{5,} M_{6,} M_{7}, \\
M_{8,} M_{10}\end{array}$ & $\begin{array}{l}M_{1,} M_{2,} M_{3}, M_{4,} M_{5}, M_{6,} M_{7,} M_{8,} M_{9} \\
M_{10}\end{array}$ & $\begin{array}{l}M_{1,} M_{2,} M_{3,} M_{4,} M_{5,} M_{6,} \\
M_{7,} M_{8,} M_{10}\end{array}$ & I \\
\hline 2 & $M_{9}$ & $M_{9}$ & $M_{9}$ & $M_{9}$ & II \\
\hline
\end{tabular}




\section{ARAŞTIRMA BULGULARI}

Tersine lojistik motivasyon faktörlerinin arasındaki ilişkilerin Vestel'in faaliyet bağlamında ve kuramsal çerçevede incelenmesi sonucunda iki farklı hiyerarşik yapıya ulaşıımıştır.

Vestel'in faaliyet bağlamı dikkate alınarak ulaşılan güncel hiyerarşik yapının (Şekil 3) en alt seviyesinde "kanuni yükümlülükleri yerine getirmek" motivasyon faktörünün olduğu tespit edilmiştir. Bu sonucu yorumlayan Vestel yöneticileri, firmalarında tersine lojistik aktivitelerinin yürütülmesinin ana motivasyonlarından bir tanesinin güncel durumda da gerçekten kanuni yükümlülükleri yerine getirmek olduğunu belirtmiştir. Bu motivasyon paralelinde, tersine lojistik aktivitelerine yapılacak yatırımların hiyerarşinin üst seviyelerinde yer alan diğer hedeflerin başarılmasına katkı sağlayabileceği kendileri tarafından da doğrulanmıştır. Kanuni yükümlülük çerçevesinde ürünlerin geri toplanması için tersine lojistik yatırımlarının yapılması durumunda uzun vadede müşterilerin tekrar satın alma davranışlarının beslenebileceği, kurum imajının pozitif yönde etkilenebileceği, üretim ve lojistik süreçlerinin hem daha etkin hem de Vestel'in çok hassasiyet gösterdiği şekilde çevre dostu hale gelebileceği görüşünde bulunmuşlardır.

Vestel'in faaliyet bağlamı dikkate alınarak ulaşılan hiyerarşik yapının (Şekil 3) en üst seviyesinde "finansal firsatlardan yararlanma" motivasyon faktörünün yer aldığı saptanmıştır. Vestel yöneticileri, "finansal fırsatlardan yararlanma" motivasyon faktörünü ikinci el satışlardan gelir elde etme ve geri dönen ürünlerden değerli metallerin elde edilmesi şeklinde değerlendirmiştir. Dolayısıyla, kanuni yükümlülükleri yerine getirmek için daha çok ürün geri toplanmasının firmalar için daha çok ikinci el ürün satma fırsatı sağlayacağı yorumunu yapmışlardır. Ayrıca, yapılan analiz neticesinde ortaya çıkan "finansal firsatlardan yararlanma" motivasyon faktörünün diğer motivasyon faktörlerine bağlı hedeflerin gerçekleşmesine neden yol açmadığı sonucunu da yorumlamışlardır. Vestel yöneticileri, bu durumu ikinci el satışların Türkiye'de henüz yeterince rağbet görmemesi ve firmaların marka değerini azaltıcı nitelikte olabilmesi sebeplerine bağlamıştır. Aynı şekilde, diğer bir finansal fırsat olan değerli materyallerin firmalar tarafından çıkarılabilmesi için de ekipman yatırımları yapılması gerektiğini vurgulamışlardır. Vestel yöneticileri, günümüzde firmaların bu yatııımı henüz yeterince kârlı görmediğini belirterek neden "finansal firsatlardan yararlanma" motivasyon faktörünün diğer motivasyonlara bağlı hedeflerin gerçekleşmesine etkisinin olmadığı bulgusuna yorum getirmiştir.

Kuramsal çerçevede tersine lojistik motivasyon faktörlerinin ilişkilerinin değerlendirilmesi ile ulaşılan hiyerarşi (Şekil 4) çeşitli farklılıklar göstermektedir. Öncelikle, Vestel'in tersine lojistik motivasyon faktörleri hiyerarşisine nazaran daha az seviyeden (2 seviyeden) oluşmaktadır.

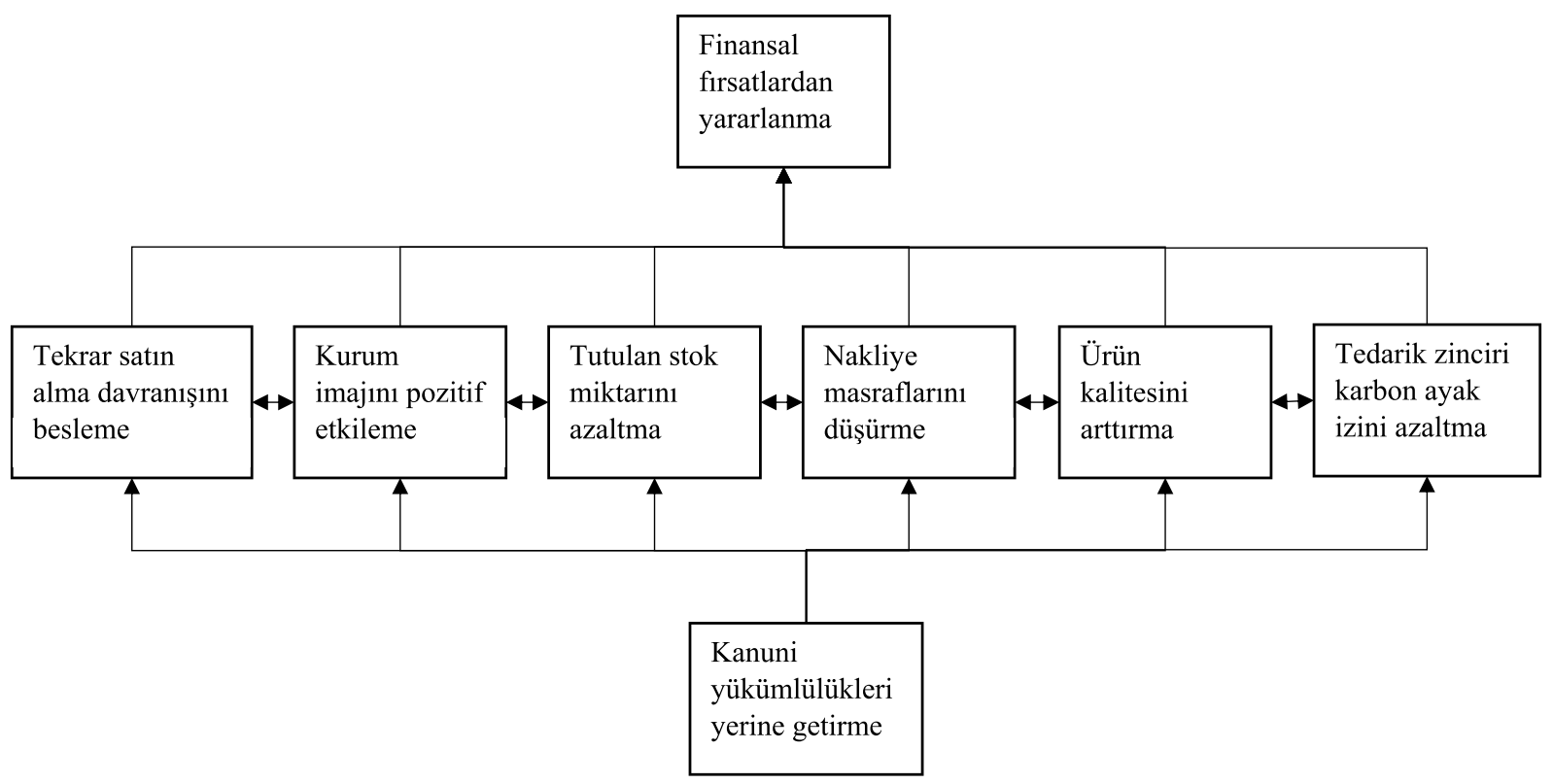

Şekil 3: Vestel'in Tersine Lojistik Motivasyon Faktörleri Hiyerarşisi 
Bu fark normal olarak karşılanabilir; çünkü analizde bağlamsal kısıtların yok sayılması motivasyon faktörleri arasında daha çok direk ve endirekt etkilerin tespit edilmesini sağlamaktadır. Bunun neticesi olarak da analizde kullanılan 10 motivasyon faktöründen 9'unun aynı hiyerarşik seviyede yer aldığı gözükmektedir. Kuramsal çerçevede yapılan analiz sonucu ulaşılan hiyerarşide dikkat çeken en önemli farklılık ise temel itici motivasyon faktörünün değişiklik göstermiş olmasıdır. Ulaşılan bu hiyerarşinin en alt seviyesinde "kanuni yükümlülükleri yerine getirme" motivasyon faktörü yerine "ürün kalitesini arttırma" motivasyon faktörü yer almaktadır. Vestel yöneticileri, tersine lojistik aktivitelerinin etkin yönetilmesi durumunda, özellikle tüketicilerin yaşadığı problemler sonucunda oluşan geri ürün akışının ürün kalitesini arttırmak için bir fırsat olabileceğini belirtmiştir. Ürün kalitesini arttırmanın da, Şekil 2'te listelenen diğer tersine lojistik motivasyon faktörlerine bağlı hedeflerin ulaşılmasına oldukça yardımcı olabileceğini teyit etmişlerdir. Kaliteli ürünün müşteri memnuniyetini arttırarak tekrar satın alma davranışını besleyebileceğini ve kurum

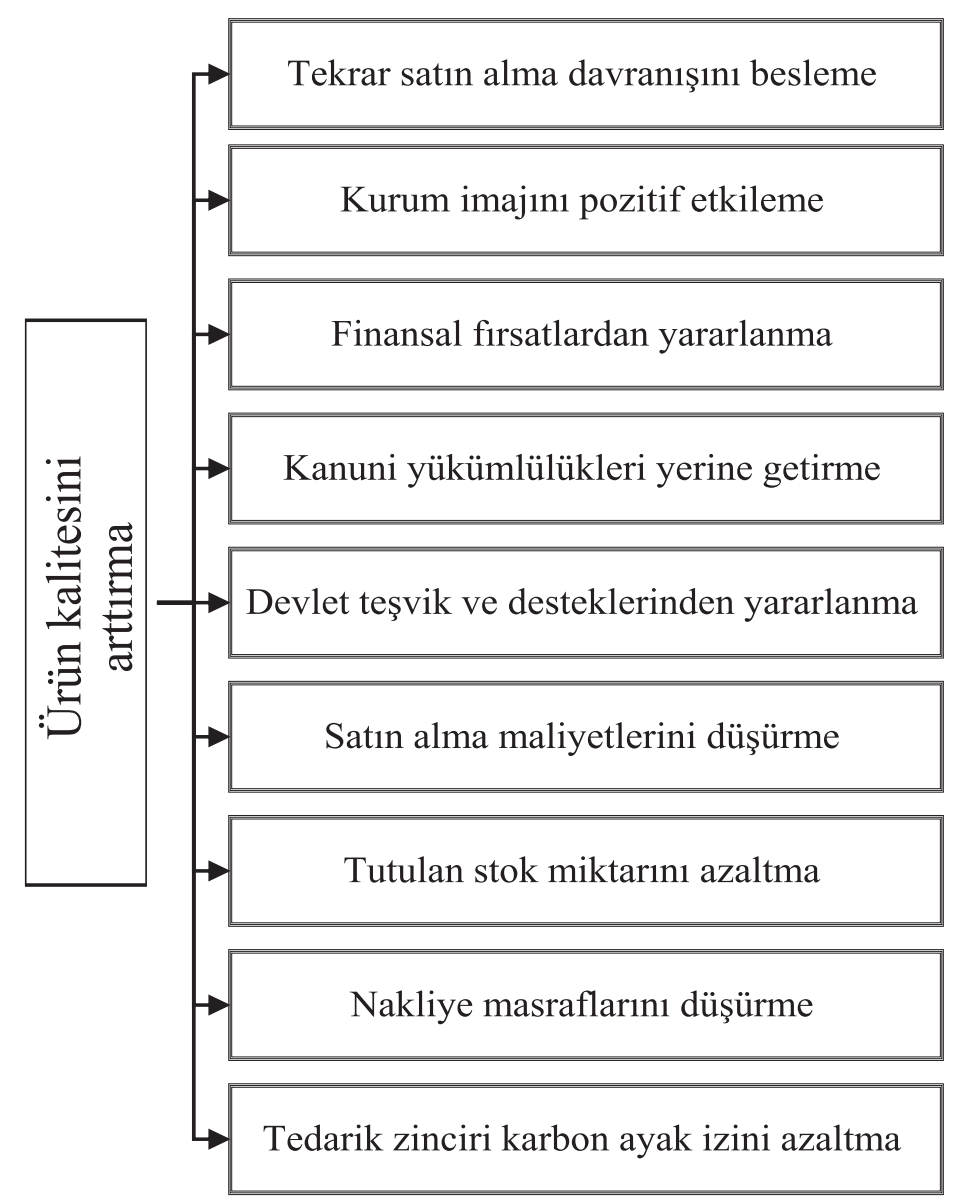

Şekil 4: Kuramsal Çerçevede Tersine Lojistik Motivasyon Faktörleri Hiyerarşisi imajını pozitif şekilde etkileyebileceğini örnek olarak göstermişlerdir. Aynı şekilde, yaşam döngüsü sona eren kaliteli ürünlerin parçalarının tekrar kullanılarak birçok finansal ve operasyonel fayda elde edilebileceğini de ifade etmişlerdir.

\section{SONUÇ}

Üretici firmaları tersine lojistik uygulamalarına yönelten motivasyonları hiyerarşik bir yapıda göstermek bu çalışmanın ana amacını oluşturmuştur. Bu amaç doğrultusunda tersine lojistik motivasyon faktörleri literatürden derlenmiş ve "yorumlayıcı yapısal modelleme" yöntemi ile analiz edilmiştir. Vestel firmasının tersine lojistik aktiviteleri üzerinde yapılan bu analiz sonucunda, Vestel'i tersine lojistik aktivitelerine yönelten ana motivasyonun "kanuni yükümlülükleri yerine getirmek" olduğu tespit edilmiştir. Bu sonucun temel nedeninin Avrupa Birliği müzakereleri çerçevesinde ülkemizin yönetmeliklerini $A B$ ülkeleri ile uyumlaştırma çabası olduğu yorumu yapılabilecektir. 2019 yılı itibariyle $A B$ mevzuatı, üye ülkelerde elektrik-elektronik sektöründe faaliyet gösteren firmaların son 3 yılda piyasaya sürdükleri ürünlerin ağırlığının \%65'i kadarını geri toplamasını ön koşmaktadır (AEEE Kontrolü Yönetmeliği Belediye Uygulama Rehberi, 2016). Çevre ve Şehircilik Bakanlığı́nın hazırladığı AEEE yönetmeliği değişiklik taslağı, şu an için firmalardan piyasaya sürdükleri malların \%5'i kadarının geri toplamasını şart koşarken, 2030 yılında bu oran \%40'a çıkacaktır. Belirtilen oranların firmalar tarafından tutturulamaması durumunda ağır yaptırımların uygulanabilecek olması firmaları kaygılandırmaktadır. Bu durum, "kanuni yükümlülükleri yerine getirmek" motivasyon faktörünün hiyerarşinin en alt seviyesinde "itici" tersine lojistik motivasyon faktörü olarak tespit edilmesiyle doğrulanmıştır.

$\mathrm{Bu}$ araştırmada ek olarak kuramsal çerçevede analiz yapılarak, tersine lojistik faktörleri hiyerarşisinin araştırma yapılan bağlama ve incelenen firmaya özgü koşullara bağlı olarak değişip değişmediği kontrol edilmiştir. Yapılan bu kuramsal analiz sonucunda ortaya çıkan hiyerarşik yapının farklılık gösterdiği tespit edilmiştir. Ortaya çıkan bu yeni hiyerarşik yapıda, firmaları tersine lojistik aktivitelerine yöneltecek ana unsurun "ürün kalitesini arttırmak" olması gerektiği saptanmıştır. 
Bu çalışmanın sonuçlarının kurumsal teorinin ortaya koyduğu çerçeve üzerinden yorumlanması mümkündür. Kurumsal teori, yöneticilerin kararları üzerinde etkisi olan baskı faktörlerini 'mecburi', 'taklitçi' ve 'normatif' olarak listelemektedir (DiMaggio ve Powell, 2000). Bu baskılardan ilki olan'mecburi' baskı, firmaların yasal zorunluluklarını yerine getirmesini, bir diğer ifadeyle devletin koyduğu yönetmeliklere uygun hareket edilmesi gerekliliğini ifade etmektedir. Firmaların başarılı rakiplerini taklit ederek başarıyı yakalamaya çalışmaları ise "taklitçi" baskı faktörü ile açıklanmaktadır. Üçüncü kurumsal baskı olan "normatif" baskı ise firmaların toplumun onayladığı aktivite ve faaliyetlerde bulunma durumunu ifade etmektedir. Huang ve Yang (2014), bu kurumsal etkilerin firmaların tersine lojistik aktivitelerine yönelmeleri üzerindeki etkilerini incelemiştir. Yazarlar, "mecburi" baskının devletten, "taklitçi" baskının rakiplerden ve "normatif" baskının ise müşterilerden kaynaklandığını varsayarak bu baskı faktörlerinin firmaların performansına etkilerini göstermiştir.

$\mathrm{Bu}$ araştırmanın temel teorik katkısı kurumsal teorinin ortaya koyduğu 3 kurumsal baskı seviyelerinin araştırma yapılan bağlama bağlı olarak değişebileceğini göstermesidir. Vestel firmasının tersine lojistik motivasyon faktörleri hiyerarşisine bakıldığında "kanuni yükümlülükleri yerine getirme" Türkiye gibi gelişen ülkelerde "mecburi" baskının tersine lojistik aktivitelerine yönelmek için temel kurumsal baskı faktörü olduğunu ortaya koymaktadır. Kuramsal analiz çerçevesinde ulaşılan tersine lojistik motivasyon faktörleri hiyerarşisinde ise durum farklı gözükmektedir. Bu hiyerarşinin temelini oluşturan "ürün kalitesinin arttırılması" motivasyon faktörünü daha çok "taklitçi" baskı faktörü ile ilişkilendirmek mümkündür. Firmalar, tersine lojistiği rekabetçiliklerini arttırmak için kullanmaktadır. Dolayısıyla firmalar tersine lojistik aktivitelerine gerekli önemi verirse, ürün kalitesinin sürekli artmasını sağlayan dinamik bir yetenek (Eisenhardt ve Martin, 2000) kazanma yolunda büyük bir adım atacaktır.

Bu çalışmanın sonuçları, hem firma yöneticilerine hem de politika yapıcılarına önemli çıkarımlar yapmaya olanak vermektedir. Vestel'in güncel tersine lojistik motivasyon faktörleri hiyerarşisi, firmaların tersine lojistiğe yönelmesinin en önemli nedenini yönetmeliklere uyma gerekliliği olarak göstermek- tedir. Bu durum her ne kadar diğer hedeflerin de başarılmasına katkı sağladığından devletin müdahalesinin isabetli olduğu yorumu yapılabilecek olsa da idealin altında bir sonuç yaratabileceği göz ardı edilmemelidir. AEEE yönetmeliği, genel olarak ürünlerin geri toplanması üzerine kurallar koymuştur; fakat toplanan ürünlerden yüksek geri kazanım elde edilmesini sağlayacak düzenlemeler bu yönetmelikte henüz yeterince mevcut değildir. Dolayısıyla yöneticiler, sadece kanuni yükümlülüklerini yerine getirmek için ürün geri toplamaya yoğunlaşırsa firmaların tersine lojistik aktivitelerinden elde edeceği fayda düşük seviyede kalacaktır. Eğer yöneticiler firmalarının tersine lojistik süreçlerinden maksimum fayda elde etmesini istiyorsa kuramsal çerçevede yapılan analiz sonucu ortaya çıkan hiyerarşideki gibi tersine lojistik uygulamalarının temel motivasyonunu "ürün kalitesini arttırma" gibi içsel bir motivasyon haline dönüştürebilmelidir. Aynı şekilde, politika yapıcılar da mümkün olduğunca yönetmelikleri ceza vermek üzerine kurgulamamalıdır. Aksine, yönetmelikler teşvik ve ödüllendirmek üzerine tasarlanarak firmaların istekli bir şekilde tersine lojistik aktivitelerine yönelmeleri sağlanabilmelidir.

Gelecek çalışmalar, bu araştırmanın kısıtlarından yola çıkarak, firmaları tersine lojistik uygulamalarına yönelten motivasyon faktörleri arasındaki ilişkileri daha iyi ortaya koyabilecektir. Her ne kadar bu araştırmada tersine lojistik motivasyonlarına bağlı hedeflerin birbirlerini nasıl etkilediği gözlemlenebilse de bu etkilerin büyüklüğünü gözlemlemek için sayısal çalışmalara intiyaç vardır. Bir diğer yandan, bu araştırmada tersine lojistik süreçleri incelenen Vestel'in büyüklüğünün Türkiye'yi temsil edebilecek boyutta olmasına rağmen, ulaşılan güncel tersine lojistik motivasyon faktörleri hiyerarşisinin bir firmadan yola çıkılarak oluşturulduğu unutulmamalıdır. Gelecek çalışmaların bu araştırmada yapılan analizi, elektrik elektronik sektöründe faaliyet gösteren diğer büyük ve orta ölçekli firmalara uygulaması, bu araştırmanın sonuçlarının doğrulanabilmesi ve genelleştirilebilmesi adına faydalı olacaktır. Ayrıca bu araştırmada elektrik-elektronik sektörü bir bütün halinde analiz edilmiştir. Gelecek çalışmaların bu analizi diğer sektörler üzerinde veya elektrik-elektronik sektörünün alt sektörleri üzerinde yapması farklı koşullara bağlı olarak bu araştırmada elde edilen sonuçların değişip değişmeyeceğini görmek adına yararlı olacaktır. 


\section{KAYNAKLAR}

Agrawal, S., Singh, R. K. ve Murtaza, Q. (2015) “A literature review and perspectives in reverse logistics" Resources, Conservation and Recycling, 97: 76-92.

Aksen, D., Aras, N., ve Karaarslan, A. G. (2009) “Design and analysis of government subsidized collection systems for incentive-dependent returns" International Journal of Production Economics, 119(2): 308-327.

Atık elektrikli ve elektronik eşyalar (AEEE) kontrolü yönetmeliği (2012), Resmi Gazete, adres: http://www. resmigazete.gov.tr/eskiler/2012/05/20120522-5.htm (17.04.2017).

Atık Elektrikli ve Elektronik Eşyaların Kontrolü Yönetmeliği Belediye Uygulama Rehberi (2016), https:// recturkey.files.wordpress.com/2016/11/aeee_rehberi. pdf (12.05.2017) ISBN: 978-975-6180-45-7

Attri, R., Dev, N., ve Sharma, V. (2013). "Interpretive structural modelling (ISM) approach: an overview" Research Journal of Management Sciences, 2(2): 3-8.

Bai, C., ve Sarkis, J. (2013) “Flexibility in reverse logistics: a framework and evaluation approach" Journal of Cleaner Production, 47: 306-318.

Bernon, M., Rossi, S., ve Cullen, J. (2011) “Retail reverse logistics: a call and grounding framework for research" International Journal of Physical Distribution \& Logistics Management, 41(5): 484-510.

Biehl, M., Prater, E., ve Realff, M. J. (2007) "Assessing performance and uncertainty in developing carpet reverse logistics systems" Computers \& Operations Research, 34(2): 443-463.

Blackburn, J. D., Guide, V. D. R., Souza, G. C., ve Van Wassenhove, L. N. (2004) "Reverse supply chains for commercial returns" California management review, 46(2): 6-22.

Carter, C. R., ve Ellram, L. M. (1998) "Reverse logistics: a review of the literature and framework for future investigation" Journal of business logistics, 19(1): 85.

Daugherty, P. J., Myers, M. B., ve Richey, R. G. (2002) "Information support for reverse logistics: the influence of relationship commitment" Journal of Business Logistics, 23(1): 85-106.

Demirel, E., Demirel, N., ve Gökçen, H. (2016) "A mixed integer linear programming model to optimize reverse logistics activities of end-of-life vehicles in Turkey" Journal of Cleaner Production, 112: 2101-2113.

DiMaggio, P. J. ve Powell, W. W. (2000) "The iron cage revisited institutional isomorphism and collective rationality in organizational fields"In Economics Meets
Sociology in Strategic Management (143-166). Emerald Group Publishing Limited.

Eisenhardt, K. M., ve Martin, J. A. (2000) "Dynamic capabilities: what are they?" Strategic management journal: 1105-1121.

Elday (2015) https://elday.org/aeee/aeee-nedir/tanim. (24.04.2017).

Fleischmann, M., Van Nunen, J. A., ve Gräve, B. (2003) "Integrating closed-loop supply chains and spare-parts management at IBM" Interfaces, 33(6): 44-56.

Govindan, K., Palaniappan, M., Zhu, Q., ve Kannan, D. (2012) "Analysis of third party reverse logistics provider using interpretive structural modeling" International Journal of Production Economics, 140(1): 204-211.

Huang, Y. C., ve Yang, M. L. (2014) "Reverse logistics innovation, institutional pressures and performance" Management Research Review, 37(7): 615-641.

Huscroft R. J., Hazen T. B., Hall J. D., Skipper B. J., ve Hanna B. J. (2013) "Reverse logistics: past research, current management issues, and future directions" The International Journal of Logistics Management, 24(3): 304-327.

Janes, F. R. (1988). "Interpretive structural modelling: a methodology for structuring complex issues" Transactions of the Institute of Measurement and Control, 10(3): 145-154.

Jayaraman, V., ve Luo, Y. (2007) "Creating competitive advantages through new value creation: a reverse logistics perspective" The Academy of Management Perspectives, 21(2): 56-73.

Jayaraman, V., Ross, A. D., ve Agarwal, A. (2008)"Role of information technology and collaboration in reverse logistics supply chains" International Journal of Logistics: Research and Applications, 11(6): 409-425.

Kalkınma Bakanlığı Elektronik Çalışma Grubu Raporu (2015),“Onuncu Kalkınma Planı 2014-2018”, http://www. kalkinma.gov.tr/Pages/OzellhtisasKomisyonuRaporlari. aspx, (24.04.2017). ISBN 978-605-9041-24-9.

Kara, S., Rugrungruang, F., ve Kaebernick, H. (2007) "Simulation modelling of reverse logistics networks" International Journal of Production Economics, 106(1): 61-69.

Kulshreshtha, P., ve Sarangi, S. (2001) "No return, no refund": an analysis of deposit-refund systems" Journal of Economic Behavior \& Organization, 46(4): 379-394.

Kumar, S., ve Putnam, V. (2008) "Cradle to cradle: Reverse logistics strategies and opportunities across three 
industry sector". International Journal of Production Economics, 115(2): 305-315.

Öztürk, T. (2015) "Generation and management of electrical-electronic waste (e-waste) in Turkey" Journal of Material Cycles and Waste Management, 17:411-421.

Ravi, V., ve Shankar, R. (2005) "Analysis of interactions among the barriers of reverse logistics" Technological Forecasting and Social Change, 72(8): 1011-1029.

Ravi, V. (2012)"Evaluating overall quality of recycling of e-waste from end-of-life computers" Journal of Cleaner Production, 20(1): 145-151.

Rogers, Dale S., ve Ronald S. Tibben-Lembke. (1999). "Going backwards: reverse logistics trends and practices" Vol. 2. Pittsburgh, PA.

Silva, D. A. L., Renó, G. W. S., Sevegnani, G., Sevegnani, T. B., ve Truzzi, O. M. S. (2013) "Comparison of disposable and returnable packaging: a case study of reverse logistics in Brazil" Journal of Cleaner Production, 47: 377-387.

Škapa, R., ve Klapalová, A. (2012) “Reverse logistics in Czech companies: increasing interest in performance measurement" Management Research Review, 35(8): 676-692.

Sorkun, MF ve Onay, M. (2016) "Ürün Modülerliğinin Ters Lojistik Süreçleri Üzerinden Tedarik Zinciri Stratejilerine Etkisi" Sosyal ve Beşeri Bilimleri Dergisi, 8(2): 41-57 ISSN: $1309-8039$.
Sorkun, MF ve Onay, M. (2018)"The Effects of Companies' Reverse Logistics Motivations on Their Reverse Logistics Networks" In: Hasan Dincer, Ümit Hacioglu, Serhat Yüksel (eds) Strategic Design and Innovative Thinking in Business Operations. Springer, Cham

Srivastava, S. K. (2008) "Network design for reverse logistics" Omega, 36(4): 535-548.

Tibben-Lembke, R. S., ve Rogers, D. S. (2002) "Differences between forward and reverse logistics in a retail environment" Supply Chain Management: An International Journal, 7(5): 271-282.

Tibben-Lembke, R. S. (2002) “Life after death: reverse logistics and the product life cycle" International Journal of Physical Distribution \& Logistics Management, 32(3): 223-244.

Vestel Şirketler Grubu (2016). https://www.vestel.com. tr/vestelsirketlergrubu (24.04.2017).

Warfield, J. N. (1974). “Toward interpretation of complex structural models" IEEE Transactions on Systems, Man, and Cybernetics, 4(5): 405-417.

Ye, F., Zhao, X., Prahinski, C., ve Li, Y. (2013) “The impact of institutional pressures, top managers' posture and reverse logistics on performance-Evidence from China" International Journal of Production Economics, 143(1): 132-143. 